SILVIO RICARDO DEMÉTRIO

\title{
POR UM JORNALISMO CONTRACULTURAL: LINHAS DE FUGA NO NEW JOURNALISM
}

Tese apresentada ao Programa de Pós Graduação em Teoria e Pesquisa em Comunicação, Linha de Pesquisa Jornalismo e Linguagem da Escola de Comunicação e Artes da Universidade de São Paulo, como exigência parcial para a obtenção do título de Doutor em Teoria e Pesquisa em Comunicação, sob a orientação da Prof. Mayra Rodrigues Gomes.

SÃO PAULO

2007 
SILVIO RICARDO DEMÉTRIO

\section{POR UM JORNALISMO CONTRACULTURAL: LINHAS DE FUGA NO NEW JOURNALISM}

Tese apresentada ao Programa de Pós Graduação em Teoria e Pesquisa em Comunicação, Linha de Pesquisa Jornalismo e Linguagem da Escola de Comunicação e Artes da Universidade de São Paulo, como exigência parcial para a obtenção do título de Doutor em Teoria e Pesquisa em Comunicação, sob a orientação da Prof. Mayra Rodrigues Gomes.

SÃO PAULO

2007 
BANCA EXAMINADORA

Membro 1

Membro 2

Membro 3

Membro 4

Membro 5 
Resumo

A argumentação da presente tese parte do New Journalism como plataforma para discussões sobre a linguagem jornalística. A Contracultura enquanto fenômeno político serve de enquadramento histórico sobre o qual se trabalha a noção de uma política antidisciplinar como recurso de enfrentamento às inscrições da imprensa sobre $\mathrm{o}$ plano da reprodução das ideologias hegemônicas.

\begin{abstract}
The following thesis is an argumentation about the New Journalism as a plataform for the discutions envolving the ordinary journalistic language. The Counterculture is taken as a politic event featuring the historic plan wich is discussed by the anti-disciplinary protest. This notion is taken as a estrategy to resist against the passive hegemonic ideological reproduction.
\end{abstract}

Palavras-chave: Novo Jornalismo, Contracultura, Teoria da Comunicação, Deleuze e Guattari.

Key-words: New Journalism, Counterculture, Communications Theory, Deleuze and Guattari. 


\section{Agradecimentos}

A todos aqueles que souberam entender. Em primeiro lugar a toda minha família, indistintamente - uma dívida de afeto. Obrigado à minha orientadora Mayra Rodrigues Gomes pela paciência e pelas pistas com as quais desconstruir delírios e demônios pessoais. Obrigado aos alunos que encontro todos os dias e que me fazem gostar da profissão tanto de jornalista quanto de professor. Obrigado aos amigos - em especial a Gutemberg Medeiros. 
Para Dona Dora Demétrio, minha mãe

In memorian 
"A coragem está, entretanto, em aceitar escapar em vez de viver quieta e hipocritamente em falsos refúgios. Os valores, as morais, as pátrias, as religiões e as certezas privadas que nossa vaidade e nossa complacência para conosco nos outorgam generosamente, têm tantas moradas enganosas quanto o mundo arranja para aqueles que assim pensam manter-se, de pé e em repouso, entre as coisas estáveis. Eles não sabem nada dessa grande debandada em que se vão, ignorantes de si mesmos, no rumor monótono de seus passos cada vez mais rápidos que os levam impessoalmente num grande movimento imóvel. Escapamento diante do escapamento. [Seja um desses homens] que, tendo tido a revelação da deriva misteriosa, não suportam mais viver nas falsidades da morada."

Deleuze e Guattari 


\section{Sumário}

$\begin{array}{ll}\text { Introdução } & 06\end{array}$

1.Da informação ao desejo 08

2.Para trair o jornalismo 44

3.Deleuze e Guattari e as linhas de fuga $\quad 58$

4.New Journalism - um modelo contracultural 72

$\begin{array}{ll}\text { Conclusão } & 90\end{array}$

Referências Bibliográficas $\quad 92$ 


\section{Introdução}

A proposta de trabalho que se segue é primeiramente traçar o mapa do fenômeno histórico, social e político conhecido como "Contracultura" a partir de outro fenômeno contemporâneo específico da imprensa americana que ficou conhecido como New Journalism. Tais reflexões têm como ponto de articulação teórica a definição de Contracultura elaborada pelo sociólogo americano Theodor Roszak e a obra conjunta de Gilles Deleuze e Félix Guattari, especialmente no tocante ao conceito de linha de fuga. Todo esse enquadramento serve como plataforma para discussões pertinentes à experimentação estética com o texto jornalístico - característica central do New Journalism. Aspectos concernentes à forma, portanto, são aqui tomados como fundamentais em relação às possibilidades de reformulação dos parâmetros que norteiam a prática jornalística.

No primeiro capítulo percorre-se o perímetro da formação teórica do campo das pesquisas em comunicação de maneira a elaborar um panorama de inscrição das idéias e conceitos deleuzianos no contexto das teorias da comunicação e, de forma derivada, dos fundamentos e princípios que orientam as práticas dos meios de comunicação concomitantemente ao jornalismo. A idéia norteadora das discussões apresentadas é a relação fundamental entre informação e redundância decorrente do modelo de processo da comunicação de Shannon e Weaver - modelo que se institui no contexto americano das escolas de comunicação e que prevalece de maneira recorrente nos procedimentos convencionais do jornalismo e das práticas midiáticas como um todo. O percurso chega até as considerações do pós-estruturalismo em confronto com o discurso da pós-modernidade. A intenção é caracterizar um 
direcionamento do foco das pesquisas em comunicação para as relações entre o plano da técnica e da subjetividade no contexto contemporâneo.

O segundo capítulo parte da leitura da obra que Deleuze escreveu em parceria com a jornalista Claire Parnet, Diálogos, e busca delinear um diagrama das relações pelas quais esses autores sustentam sua leitura das limitações do jornalismo e das práticas de mídia convencionais. Deleuze e Parnet encontram na redundância, conceito operatório descrito pelo modelo de Shannon e Weaver, o fundamento dessas práticas e propõem uma reconfiguração das mesmas a partir do conceito de linha de fuga explicado no capítulo terceiro.

No quarto e último capítulo é desenvolvida a proposta de um modelo de jornalismo antidisciplinar, contracultural, tomando como exemplo o fenômeno do New Journalism. Historicamente os novos jornalistas, como ficaram conhecidos, surgiram erraticamente a partir do começo da década de 60 de forma não orgânica. $O$ primeiro a escrever uma grande reportagem jornalística valendo-se de recursos literários como ferramentas foi Truman Capote. Sua reportagem In Cold Blood (1962) foi a plataforma para a produção subseqüente de nomes como Tom Wolfe (The Eletric Cool-Aid Acid Test), Hunter Thompson (Fear and Loathing in Lãs Vegas) e Norman Mailer (The Armies of the Night), para ficar nos mais conhecidos. Também estão sob a chancela do New Journalism as incontáveis experiências da imprensa underground como o San Francisco Oracle, publicado pelo editor Allen Cohen - periódico hippie que hoje alça status de representante da arte psicodélica com suas capas art-noveau e diagramação exuberante. 


\section{Da informação ao desejo}

\section{O percurso da Comunicação}

Desde a discussão aberta pelos frankfurtianos em torno de sua legitimidade, a cultura de massa (e dentro dela necessariamente o jornalismo) é vista como o resultado de um empobrecimento estético que leva à impotência política. Segundo Adorno e Horkheimer o processo histórico que levou a sociedade industrial a rebater sobre o plano da cultura a lógica da mercadoria fez com que se estabelecesse uma dialética de inversão dos ideais iluministas. A cultura, que seria a expressão máxima da razão emancipatória, converte-se no seu oposto, instrumento de "mistificação das massas". Disto resulta a reificação das massas pela regressão estética que despotencializa a dimensão política dos bens culturais. Para Adorno e Horkheimer não existe cultura de massa, mas tão somente a indústria cultural - fenômeno ideológico que converte o valor político e existencial da cultura no valor puramente pragmático e abstrato da mercadoria. Esta posição assumida pelos filósofos é eivada de um pessimismo apocalíptico que não vê, por exemplo, nenhum valor cultural verdadeiro em expressões como o jazz - certamente um exagero cometido por Adorno.

Esta posição cerrada dos frankfurtianos será relativizada mais tarde, a partir da década de 60, com os Cultural Studies, quando a cultura de massa deixa de ser abordada como um fenômeno totalizante e homogêneo. Autores como Raymond Williams, Stuart Hall e Edward Thompson empreendem uma análise da formação da cultura nas classes subalternas partindo das bases concretas sobre as quais esta formação se dá e não projetando sobre a mesma o espectro de uma alta cultura burguesa que lhe é estrangeira. A partir dos 
Cultural Studies a cultura de massa passa a ser entendida como cultura da mídia, sendo irrefutável o fato de que a formação cultural tanto das elites quanto das classes subalternas se serve de material proveniente desta origem. Não há espaço numa sociedade industrializada que não seja apanhado na rede de relações que os sistemas de comunicação traçam. Portanto se persiste uma divisão da sociedade em função dos meios de produção, a cultura da mídia é também um plano sobre o qual este conflito se projeta. É possível ler na cultura de massa as vozes minoritárias que resistem aos modos de semiotização dominante da sociedade.

Vem daí uma importante assimilação do pós-estruturalismo francês pelo espírito crítico dos Cultural Studies. A desconstrução da episteme do estruturalismo pelo pós-estruturalismo levou este, até onde pudemos detectar, no pensamento de Deleuze e Guattari, a uma teoria das multiplicidades. O que sugere uma confluência com os Cultural Studies a partir do conceito de multiculturalismo. Confluência em relação à concepção pluralista do social que perpassa ambos os campos teóricos, como também dos sentidos minoritários que aí desenvolvem sua luta para constituir enunciados frente aos modos de semiotização dominante.

\begin{abstract}
"O pós-estruturalismo, ao efetuar uma crítica política dos valores iluministas, representa um aprofundamento da noção de democracia. Em sua crítica, os pós-estruturalistas argumentam que as democracias liberais modernas constroem a identidade política com base em uma série de oposições binárias (por exemplo, nós/eles, cidadão/não-cidadão, responsável/ irresponsável, legítimo/ ilegítimo) que têm o efeito de excluir certos grupos culturais ou sociais. "l
\end{abstract}

Muitas vezes a implosão de uma perspectiva de grande síntese do conhecimento ocidental denunciada pelo pós-estruturalismo o aproxima de

\footnotetext{
${ }^{1}$ PETERS, Michael. Pós -estruturalismo e Filosofia da Diferença - uma introdução. Belo Horizonte, Autêntica, 2000. p.41.
} 
certos aspectos do discurso sobre a pós-modernidade. De acordo com Michael Peters essa aproximação é imprecisa porque ilusória. O pós-estruturalismo tem como objeto de uma crítica filosófica os aspectos totalizantes da teoria estruturalista, fundamentalmente a ambição de concretizar o projeto semiológico de Saussure - a criação de uma "ciência geral de todos os processos de significação". Para Peters a pós-modernidade compreende um âmbito muito mais histórico e cultural.

\section{Modernidade e Pós-modernidade}

Assim como o século XIX foi marcado pela emergência de um pensamento voltado para a potência da história, na esteira de Hegel e Marx, as forças políticas, sociais, econômicas e culturais do século XX engendraram uma condição na qual a teleologia das grandes utopias construídas pelos ideais iluministas demonstra um ponto de fadiga na passagem para um novo século.

Paradoxal, o tempo que se inaugura recebe diferentes nomes: pósmodernidade, modernidade tardia, modernidade reflexiva, entre outros. A polêmica está lançada e, pela profusão dos direcionamentos com que tem sido conduzida, está longe de uma resolução sintética. A modernidade enquanto expressão histórica do devir da razão segundo o Iluminismo conduziu o próprio conhecimento humano a uma profunda crise que é paradigmática. $\mathrm{O}$ saber não se encontra completamente fora dos princípios modernos que o definem na contemporaneidade, no entanto, a maneira pela qual se colocam novos objetos a este saber faz com que lacunas surjam - zonas de sombra, imprecisões, em suma, limites novos de uma nova cartografia para o conhecimento humano.

No pensamento ocidental a modernidade surge com Descartes quando este propõe uma forma de conhecimento que prescinde de uma dúvida 
metódica na interpelação do objeto pelo sujeito. É a dúvida cartesiana o elemento pelo qual a cisão entre a res cogitans e a res extensa se institui como condição fundamental do conhecimento. Dessa maneira temos que o saber moderno é dicotômico por definição. Nasce com isto uma metafísica de dois mundos em função dos quais a razão se constitui como ponte: o mundo do conhecimento e o mundo dos objetos desse conhecimento. É a razão que surge como redenção que esgota a dúvida em sua própria potência negativa. Daí o processo pelo qual se legitima o valor da certeza segundo Descartes.

A racionalidade moderna, portanto, pauta-se pela razão como instrumento pelo qual o homem pode transcender a dúvida e assim dominar, enquanto sujeito do conhecimento, tudo aquilo que se apresenta a ele como objeto. $\mathrm{O}$ devir da modernidade segundo esta sua origem é a racionalização do mundo dos objetos pelo conhecimento como transcendência do sujeito. Na linha sucinta aqui traçada que busca definir os contornos da modernidade o pensamento de Kant se situa como origem de uma segunda condição fundamental do conhecimento. À cisão cartesiana entre sujeito e objeto do conhecimento sobrepõe-se a divisão kantiana entre o âmbito do númeno e do fenômeno, entre a coisa em si e a coisa tal qual ela é percebida pelos sentidos. Segundo Kant o conhecimento só é possível em relação aos fenômenos - não há possibilidade de conhecimento da coisa em si.

No plano das determinações de ordem histórica, a modernidade traduzse pela ascensão da uma nova classe social, a burguesia. O fenômeno histórico que figura esta emergência é a Revolução Francesa. O modo de produção capitalista se estabelece no ocidente e a Revolução Industrial desencadeia um processo que transformará as relações do trabalho. Surge então o proletariado. A sociedade moderna capitalista é então, segun do o marxismo, fundamentada por uma nova cisão, agora concernente ao coletivo: a luta de classes. Ao 
inverter o idealismo hegeliano, Marx propõe a sobredeterminação das condições objetivas materiais (infraestrutura) como fundamento das relações sociais. A cultura, as instituições, enfim, a "produção espiritual" da sociedade surge como um reflexo destas condições objetivas e é determinada por ela. Como este reflexo dissimula e encobre as relações fundamentais de produção na sociedade, a infraestrutura se reveste de ideologia (superestrutura). Existe uma teleologia marxista que dota a história de um sentido mais amplo do que aquele proposto por Hegel de uma passagem da natureza para a sociedade. Para o marxismo a história desenvolve-se segundo uma linha definida pelo conflito de classes. Seu sentido é dado pelo movimento de superação dialética das contradições inerentes ao sistema capitalista. A modernidade de Marx assinala o proletariado como sujeito da história. O conhecimento se torna uma ferramenta a serviço dessa classe que, ao combater a ideologia que mascara as relações de produção, conduziria a sociedade como um todo à superação dos conflitos de classes $^{2}$. Toda cisão operada pelo estatuto do conhecimento na modernidade pressupõe um movimento de recondução dos termos a uma unidade sintética. Constituir assim um saber social para Marx é então perceber o movimento dialético pelo qual a história se constrói como resultado dessa luta. Mais uma vez o caráter dicotômico do saber na modernidade se afirma numa forma de oposição binária.

Conhecer então num sentido moderno é, de certa maneira, apartar-se, destacar-se daquilo que se busca conhecer. Constitui-se neste afastamento o sujeito do conhecimento moderno por definição. Diante disto o social enquanto objeto do conhecimento instala sua problemática: como se apartar dele? O conhecimento que se debruça sobre o social vai responder de

\footnotetext{
${ }^{2}$ É sobre esse conceito de conhecimento crítico que Gramsci, por exemplo, forjará a concepção de intelectual orgânico. O intelectual que se coloca a serviço das demandas das classes subalternas.
} 
maneiras diferentes a esta questão. Duas matrizes fundamentais são delineadas: o positivismo de Comte, que vê o método científico a partir de uma positividade absoluta, daí o seu nome, e uma segunda e profícua posição, a de um saber crítico, isto é, de um método que interroga o seu próprio estatuto em relação a seu objeto. Neste sentido Marx é definitivo em relação aos métodos das ciências sociais.

\title{
A formação do campo da comunicação
}

O campo da comunicação como saber surge como uma especialização do campo sociológico e vai reproduzir esta dicotomia em sua formação. O viés positivista é expresso pela vertente dos estudos americanos funcionalistas que se inspiram no modelo de processo da comunicação de acordo com a hipótese da agulha hipodérmica (Bullet Theory). Segundo Mauro Wolf, a comunication research organiza-se a partir dos trabalhos de Harold Lasswell. Sua conhecida fórmula Quem? Diz o que? Em que canal? Com que efeito? Estrutura as variáveis que definem o estudo da comunicação:

\begin{abstract}
"Qualquer uma destas variáveis define e organiza um sector específico da pesquisa: a primeira caracteriza o estudo dos emissores, ou seja, a análise do controlo sobre o que é difundido. Quem, por sua vez, estudar a segunda variável, elabora a análise do conteúdo das mensagens, enquanto o estudo da terceira variável dá lugar à análise dos meios. Análises da audiência e dos efeitos definem os restantes sectores de investigação sobre os processos comunicativos de massas. A fórmula de Lasswell, ordenando aparentemente o objeto de estudo segundo variáveis bem definidas, sem omitir nenhum aspecto relevante dos fenômenos em causa, na realidade depressa se transformou - e assim permaneceu durante muito tempo - numa verdadeira teoria da comunicação, em ligação estreita com o outro modelo comunicativo dominante na pesquisa, isto é, a teoria da informação." 3
\end{abstract}

\footnotetext{
${ }^{3}$ WOLF, Mauro. Teorias da Comunicação. Lisboa, Editorial Presença, 1999. pp.29-30.
} 
Segundo Lasswell, as variáveis de sua fórmula estruturam a pesquisa sobre comunicação. É no âmbito das funções sociais que a comunicação cumpre que emerge o objeto unificador da comunication research - são estas funções que definem o reconhecimento da comunicação enquanto fenômeno. É sobre tal plano que Lasswell irá recorrer a uma idéia trazida como herança da Escola de Chicago: a ecologia humana. Dessa maneira, entende-se todo contexto pelo qual se reconhece uma determinada sociedade como um complexo sistema de interações que se orientam segundo uma metaestabilidade geral do todo, tal qual nas interações entre uma determinada espécie e seu habitat. O equilíbrio metaestável, a homeoestase, ou seja, o perfeito funcionamento da organicidade do todo é o que regula o social. Mais especificamente, Lasswell elabora sua teoria segundo a metáfora do organismo social, que tem sua origem na fisiocracia - uma das matrizes da ideologia liberal que marca o subtexto funcionalista ${ }^{4}$. O organismo social se estrutura segundo funções que se somam num todo de modo a manter o equilíbrio de seu funcionamento diante da troca de estímulos com o meio exterior. A comunicação é exatamente o elemento-chave que na sociedade garante a regulação desse trânsito com sua exterioridade. Aqui o funcionalismo de Lasswell demonstra forte influência da psicologia behaviorista americana, entendendo o contexto social segundo um esquema estímulo-resposta pavloviano. É subjacente à retórica positivista do funcionalismo uma concepção antropológica em que o fora, a exterioridade, o outro, são vistos como uma ameaça ao equilíbrio interno de uma dada sociedade. Cabe à comunicação cumprir seu papel como instrumento pelo qual é garantida a ordem estabelecida:

\footnotetext{
${ }^{4}$ MATTELART, Armand e Michélle. A História das Teorias da Comunicação. São Paulo, Loyola, 2000.
} 
“ $O$ organismo unicelular ou o grupo mais complexo tende a manter um equilíbrio interno e a reagir às mudanças de ambiências, de forma a manter esse equilíbrio. O processo de reação aos estímulos do meio exige maneiras especializadas de organizar as partes do todo para uma ação harmoniosa. (...)

(...) Os processos de comunicação da sociedade humana, quando examinados em pormenor, revelam equivalência em relação às especializações encontradas no organismo físico $e$ nas sociedades animais inferiores.(...)

(...) Para exprimir a questão em outros termos: se a 'verdade' não é compartilhada, os elementos dominantes esperam mais o conflito interno do que o ajustamento harmonioso ao meio externo do Estado. Daí o controle dos canais de comunicação, na esperança de organizar-se a atenção do conjunto da comunidade, de tal forma a limitarem-se as respostas àquelas considerações favoráveis à posição de poder das classes dominantes." 5

Para Lasswell, a comunicação é uma especialização orgânica da sociedade, portanto funcional. Cabe a ela então cumprir seu papel vigiando, organizando a maneira pela qual o sistema vigente possa responder ao que o desestabiliza e transmitindo a herança cultural de modo que a sociedade garanta sua positividade - estas são as três funções sociais da comunicação segundo Lasswell. É uma concepção positiva do social porque avessa a qualquer historicidade que possa advir dos conflitos com a ordem vigente de valores orgânicos. A comunicação é vista sob um viés positivo também, sendo entendida como um instrumento pelo qual se preservam as relações de poder na sociedade, servindo assim de solvente de qualquer conflito que possa se instalar como uma ameaça a este poder. Neste momento fundador da comunication research Lasswell atinge o topo da tendência assinalada pela hipótese da agulha hipodérmica, isto porque a comunicação fica vinculada a uma condição de exercício do poder na sociedade. A maneira pela qual são

\footnotetext{
${ }^{5}$ LASSWELL, Harold. A Estrutura e a Função da Comunicação na Sociedade. In COHN, Gabriel (org.). Comunicação e Indústria Cultural. São Paulo, Editora Nacional, 1978. pp. 106 a 116.
} 
entendidos os processos de comunicação de massa implica, na visão de Lasswell, uma posição na qual a recepção das mensagens dos meios é passiva e assujeitada ao poder de manipulação destes. A recepção, dentro dos parâmetros fixados pelo funcionalismo na comunicação, se dá num processo unilateral em que as mensagens atravessam o social segundo uma lógica indivíduo a indivíduo, tal como num processo de vacinação em massa. Todo conflito é visto como uma algo a ser imobilizado e destituído de sua potência - a comunicação assume assim caráter de profilaxia social. A recepção é compreendida segundo um ponto de vista individual, apassivador e positivo. A sociedade funcional se constrói pela eficiência das técnicas de comunicação em massa que produzem esta passividade orgânica.

O funcionalismo vai desenvolver-se a seguir segundo um contexto no qual os pressupostos de Lasswell serão relativizados por uma abordagem empírico-experimental. Há um investimento ainda mais vigoroso nos métodos da ciência comportamental behaviorista. Se Lasswell constituiu uma teoria da comunicação ao pesquisar as técnicas de propaganda utilizadas na I Guerra Mundial, a pesquisa funcionalista vai, num segundo momento, voltar-se para os efeitos da persuasão segundo um parâmetro de performance. Segundo Wolf ${ }^{6}$,

“ (...) A abordagem deixa de ser global, incidindo sobre todo o universo dos meios de comunicação e passa a 'apontar', por um lado, para o estudo da sua eficácia persuasiva óptima $e$, por outro, para a explicação do 'insucesso' das tentativas de persuasão.",

Com a pesquisa voltada para um horizonte experimental psicológico e de trabalhos de campo eminentemente empíricos o período de proeminência

\footnotetext{
${ }^{6}$ WOLF. Op.cit. p.33.

${ }^{7}$ WOLF. Op.cit. p 34
} 
da hipótese hipodérmica é encerrado. No entanto perduram algumas considerações que vão acentuar o vínculo do funcionalismo com um ponto de vista ainda centrado no emissor como valor fundamental de seu conceito de comunicação. No movimento pelo qual a pesquisa funcionalista redireciona seus parâmetros persiste o caráter de um saber que busca racionalizar as técnicas de comunicação no intuito de otimiza-las. É certo que, como nota Wolf $^{8}$, esse redirecionamento significa uma relativização do acento sobre o emissor como elemento fundamental do processo de comunicação - admite-se pela primeira vez indicativos da incidência de elementos que influenciam o processo e que não advêm apenas do controle por parte do emissor. Todavia, o horizonte que circunscreve a consideração de aspectos ligados aos outros elementos do processo de comunicação - fatores relativos à audiência (interesse em obter a informação, exposição seletiva, percepção seletiva e memorização seletiva) e fatores relativos à mensagem (credibilidade do comunicador, ordem de argumentação, integralidade das argumentações e a explicitação das conclusões) - só se dá no sentido de ampliar a eficiência do controle do processo de comunicação pelo emissor através de uma persuasão eficiente. É nesse momento que o caráter "administrativo" da pesquisa funcionalista é instituído em plena potência. A comunicação está a serviço de uma engenharia do social.

\section{Desdobramentos do funcionalismo}

Segue-se um terceiro momento no qual vão ser estudados os "efeitos limitados" dos media. Sob a batuta de Lazarsfeld a pesquisa funcionalista administrativa volta-se principalmente para o estudo de campo das campanhas eleitorais nos EUA. Juntamente com Elihu Katz, Lazarsfeld elabora o modelo

\footnotetext{
${ }^{8}$ Ibdem.
} 
do two step flow of comunication, literalmente, fluxo de comunicação em duas etapas. Buscando compre ender os determinantes da eficiência persuasiva das campanhas, este modelo rompe definitivamente com a teoria hipodérmica ao propor que os processos de comunicação sofrem a influência decisiva dos líderes formadores de opinião. Logo, o itinerário pelo qual as mensagens dos meios de comunicação chegam até suas audiências passa pela mediação transversal desses líderes que ativam tendências latentes da massa, ao mesmo tempo que efetuam um reforço das atitudes já arraigadas em relação às tendências de voto. Um líder formador de opinião identifica-se por uma participação mais consistente nos processos políticos da comunidade, o que o coloca numa posição de redistribuidor das mensagens - o fluxo da comunicação segue então um percurso de duas etapas - rompe-se com a linearidade mecanicista do modelo hipodérmico centrado no indivíduo. O que é fundamental neste novo modelo funcionalista é que as interações sociais é que legitimam tais líderes formadores de opinião:

\begin{abstract}
"Os líderes formadores de opinião e o fluxo comunicativo a dois níveis são, pois, apenas uma modalidade específica de um fenômeno de ordem geral: na dinâmica que gera a formação da opinião pública - dinâmica em que participam também os mass media - o resultado global não pode ser atribuído aos indivíduos considerados isoladamente, deriva, pelo contrário, da rede de interações que une as pessoas umas às outras. Os efeitos dos mass media são parte de um processo mais complexo que é o da influência pessoal." 9
\end{abstract}

Os novos parâmetros que orientam os trabalhos de Lazarsfeld o conduzem, em companhia de Robert K. Merton, a propor uma outra categorização relativa às funções da comunicação na sociedade: a atribuição de status, a execução das normas sociais e a disfunção narcotizante. Esta

\footnotetext{
${ }^{9}$ WOLF. Op.Cit.p54.
} 
última é relativa à dimensão pela qual os meios de comunicação criam a ilusão de uma participação nos processos que definem a sociedade, mas é neste mesmo movimento ilusório que eles imobilizam suas audiências. Para Lazarsfeld a comunicação também possui disfunções, valores negativos que dão a medida do grau de sua eficiência persuasiva. "Disfunção narcotizante" porque, ao aspecto ilusório da participação, soma-se um valor negativo quanto à função social que se deixa de cumprir. É a lógica do enterteinement, da diversão.

\section{A síntese americana: o modelo da informação de Shannon e Weaver}

$\mathrm{O}$ modelo funcionalista administrativo expressa como um todo sua historicidade. É fruto de um contexto que atravessa a Segunda Guerra Mundial e ganha fôlego durante a emergência da Guerra Fria. Contextualizada assim a teoria funcionalista carrega consigo os valores pelos quais a persuasão da propaganda ideológica se constitui como substrato de seu modelo. Há ainda mais uma influência que, embora gerada num contexto independente, vai acentuar o positivismo dos pressupostos da pesquisa administrativa: a teoria da informação de Shannon e Weaver. Os dois engenheiros elaboraram um modelo estrutural do processo da comunicação a partir da encomenda de uma pesquisa pela AT\&T (a primeira e maior companhia americana de telecomunicações). Este modelo originariamente desenvolvido para entender o processo de comunicação entre duas máquinas simples (telefonia) acabou sendo expandido para se pensar a comunicação como um todo segundo um viés tecnicista. Em conjunto com a especificidade da teoria hipodérmica, a teoria da informação, desenvolvida na década de 30, é que concretiza a imagem do esquema pelo qual se representa a linearidade e unidirecionalidade que caracterizam a concepção funcionalista do processo de comunicação. $\mathrm{O}$ 
esquema nasce do empréstimo de conceitos e métodos da física estatística e da termodinâmica. Informação é uma grandeza estatística que atravessa as mensagens como um grau de liberdade no processo em que são elaboradas. É o grau de liberdade de escolha do emissor, da fonte. A informação marca a autonomia do emissor e coloca o destinatário da mensagem numa situação que reproduz o assujeitamento implícito na concepção da teoria hipodérmica. $\mathrm{O}$ processo de comunicação ocorreria segundo as mesmas leis que regem os fenômenos de troca de energia estudados pela termodinâmica. Mais uma vez a idéia de equilíbrio está presente. A grandeza fundamental da termodinâmica é a entropia - relativa ao grau de desorganização da energia presente em dado sistema de trocas. Há uma tendência intrínseca a toda troca energética em se alcançar um grau de organização e coerência crescente direcionado a uma estabilidade do sistema. Toda troca de energia nasce de um desequilíbrio, de uma desigualdade que tende a uma resolução organizadora dessa troca, diminuindo a 'desorganização', isto é, a entropia. O modelo pode ser exemplificado por um sistema de troca de calor. Forma-se um sistema ao se conjugar um corpo A com uma quantidade $x$ de calor com um corpo B com uma quantidade $y$. Estabelece-se uma interação na qual a energia calórica de A é diferente de B - a equação $(x-y)$ representa o grau de desorganização inicial do sistema. Essa desorganização faz com que se estabeleça um processo de troca na interação entre os corpos. Ao término do processo ambas as quantidades de calor serão equivalentes, equilibrando o sistema. Neste processo uma parcela da energia inicial do sistema se perde. A entropia é a medida do grau de desorganização do sistema, isto é, da diferença que desencadeia a troca de calor.

Shannon e Weaver recorrem a este modelo termodinâmico para afirmar a comunicação como um fenômeno de interação, de troca. Desta maneira 
existe uma desigualdade fundamental no peso da posição em que os elementos do processo de comunicação ocupam. Assim como no modelo termodinâmico o corpo com maior quantidade de calor é o ponto de partida do processo de troca de energia, no processo de comunicação é o emissor quem ocupa esta posição. Mais uma vez também a eficiência se coloca como um fundamento valorativo. A comunicação aqui é entendida segundo um viés fundamentalmente técnico: é o processo pelo qual uma mensagem que parte de um ponto A (fonte) é codificada através de sinais que permitem que ela seja transmitida por um meio físico, o canal, e que possa ser decodificada com a minimização das possibilidades de erro ao chegar num ponto $\mathrm{B}$, de modo a ser reconstruída com o maior grau de fidelidade possível. Existe um grau de incerteza relativo à transmissão que é representado pela entropia - quanto maior o grau de desorganização, de complexidade da mensagem, maior a probabilidade de que o processo não se cumpra com fidelidade. Esta complexidade relaciona-se com a quantidade de informação da mensagem, isto é, o grau de liberdade em sua formulação pela fonte. Quanto mais informação maior a entropia, menor a possibilidade de que haja fidelidade no processo, ou seja, de que a decodificação do receptor coincida com a codificação do emissor. A teoria da informação reitera o emissor como elemento definidor do processo de comunicação.

Às sucessivas cisões que o saber moderno institui como seu fundamento, a comunicação em seu estado nascente na pesquisa administrativa acrescenta a sua, modelando o processo da comunicação segundo uma abordagem que isola e torna estáticas as posições que o definem. Se o fenômeno comunicacional se define por um deslocamento de algo, por uma troca, esta troca no modelo administrativo é desigual. Logo, a comunicação, na pesquisa administrativa, incorre numa reprodução passiva da 
ideologia no sentido marxista do termo, pois ao encobrir essa desigualdade entre emissor e receptor, dissimula o caráter manipulatório de coerção que seu modelo concebe.

\section{A Escola de Frankfurt}

Enquanto saber moderno, portanto dicotômico em sua raiz, a comunicação elabora outra posição que se contrapõe ao modelo e abordagem administrativos. A segunda posição fundadora do campo da comunicação é a pesquisa crítica, que nasce do movimento mais amplo que o Instituto de Pesquisa Social de Frankfurt desencadeou na primeira metade do século vinte nas humanidades como um todo. Adorno e Horkheimer são nomes aos quais em torno de si aglutinam outros que irão atualizar o marxismo ao relê-lo em conexão principalmente com a psicanálise. É a partir dessa releitura que os frankfurtianos propõem uma crítica dos pressupostos que devem orientar toda e qualquer pesquisa social. Resgatam dessa maneira o fundamento do marxismo, no sentido que não elidem de seus pressupostos epistemológicos o fato da cisão do método científico ser problemática em relação às ciências sociais - ao fazerem incidir sobre sua reflexão um questionamento de seus próprios métodos, a teoria crítica se torna uma forma de desvelamento da ideologia. Segundo Adorno e Horkheimer existe um fundamento contraditório na constituição do próprio saber moderno. O Iluminismo como fenômeno histórico assinala a emergência da razão como instrumento de emancipação do homem. O projeto emancipatório da modernidade tem sua origem aí. A condição pela qual a razão se torna o elemento fundamental desse projeto é que ela é o elemento fundador de uma nova relação com o mundo. Onde antes prevalecia a superstição e o encantamento, a razão se constituirá numa ferramenta pela qual as forças naturais serão apropriadas pelo homem. Sua 
relação com a natureza passa a ser uma relação de dominação. A razão torna possível a domesticação das forças naturais através da técnica, que faz com que estas forças se submetam ao homem - lança luz, esclarece as causas pelas quais as forças naturais se manifestam e assim inverte a condição pela qual o homem se colocava como assujeitado à natureza. A contradição está no fato de que neste processo pelo qual a razão emancipatória do Iluminismo é direcionada ao véu ideológico de encantamento que recobria as relações do homem com a natureza, a técnica se torna o elemento pelo qual o domínio será exercido em relação ao próprio homem, tratando-o como coisa, coisificando-o. De sujeito da razão iluminista o homem se transforma em assujeitado pela técnica. É essa a "dialética" do esclarecimento que o converte em "mistificação das massas". O esclarecimento que nasce como um projeto de emancipação agrilhoa o homem à técnica que o subjuga. A sociedade não reflete mais um sentido histórico de redenção do homem através de seu conhecimento, pois este se torna instrumento de dominação e, portanto, reinveste-se nas desigualdades do conflito de classes da sociedade capitalista. As relações sociais decorrentes desta condição são embrutecedoras, pois o esclarecimento converte-se em ideologia, em mistificação. Somente um saber crítico poderá romper com este estado de coisas. Um saber que seja resultado de uma reflexão dialética que se dobre sobre suas próprias determinações no sentido de desmontar a lógica que o ameaça de reificação.

O campo por excelência onde se expressa a coisificação do homem pela técnica, segundo Adorno e Horkheimer, é a cultura. Algo do processo pelo qual a técnica passa a ser um componente de mediação das relações sociais após a Revolução Industrial atinge o cerne das produções do espírito. A cultura mediada pela técnica passa a ser apenas uma aparência, um reflexo ideológico das contradições que perpassam a sociedade capitalista. Esta 
mediação se dá exatamente através dos meios de comunicação de massa. Adorno e Horkheimer partem em sua reflexão de um questionamento sobre o estatuto da cultura diante desta mediação técnica: será possível se falar em uma cultura de massa? Para estes frankfurtianos fundadores a resposta é negativa, pois a massa é o que destrói qualquer possibilidade de cultura como expressão do projeto emancipatório da modernidade. Para Adorno e Horkheimer a expressão "cultura de massa" é um oxímoro, isto é, uma contradição de termos justapostos por uma violência simbólica que os solda e ao mesmo tempo os destitui de seu sentido. O resultado da mediação da cultura pela técnica é a projeção da lógica industrial sobre o campo da superestrutura. A cultura passa a responder segundo os imperativos da lógica industrial de produção - é uma cultura reificada destituída de seu sentido enquanto expressão da razão emancipatória. A estandardização é o signo que assinala esta produção cultural mediada pela técnica. Aquilo que na cultura é o componente pelo qual se criam identidades é convertido em seu oposto, na impossibilidade de qualquer identidade, um assujeitamento total à ideologia que serve de base à lógica industrial: o lucro. Daí Adorno e Horkheimer descartarem a possbilidade de uma cultura de massa em detrimento de um fenômeno que eles irão chamar de Indústria Cultural. A lógica de produção industrial do capitalismo projetada sobre a cultura "integra" os campos da alta e da baixa cultura - arte e cultura popular - reproduzindo seu valor fundamental, o lucro, que reifica a dimensão da cultura como um todo. As tecnologias de comunicação se tornam o palco onde a mascarada da mistificação das massas persuade suas audiências em seu engodo. O Esclarecimento converte-se em seu oposto.

A posição crítica dos frankfurtianos faz da pesquisa em comunicação um questionamento dos pressupostos pelo qual a técnica direcionada pela 
lógica mercantil converte a cultura em ideologia. O poder dos meios de comunicação mais uma vez é centrado no pólo do emissor. A recepção é uma instância de assujeitamento ideológico e as mensagens são comandos que executam este processo. A historicidade desta teoria é marcada pela leitura de uma condição histórica marcada pelos pesadelos totalitários que desembocaram na II Guerra Mundial. A grande questão à qual Frankfurt buscou uma resposta foi a de como a modernidade enquanto projeto emancipatório pôde se converter no seu oposto. A técnica como mediação da cultura foi o elemento que tornou isto possível através das tecnologias de comunicação que, ao constituírem um novo contexto de relações sociais dadas por um contexto caracterizado pela massa, assassinou a cultura e em seu lugar erigiu seu totem mistificador: a Indústria Cultural. Apesar do pessimismo frankfurtiano, esta escola também apresenta oras possibilidades ao niilismo adorniano, especialmente com Walter Benjamin. A reprodutibilidade técnica das produções culturais que a técnica permite significam para Benjamim uma mudança de estatuto da obra de arte na modernidade. Ao valor de culto que fundamenta a obra de arte "aurática", a reprodutibilidade técnica contrapõe um valor de exposição que, segundo Benjamim, dota as artes industriais de um valor político. Para Benjamin a técnica que possibilita a reprodutibilidade da obra de arte e rompe com sua unicidade é um elemento pelo qual se pode politizar a estética, isto é, reverter o processo pelo qual o totalitarismo se constitui como expressão da derrocada dos ideais iluministas ao estetizar a política. 


\section{Modernidade e Pós-modernidade na comunicação}

As duas teorias fundadoras do campo da comunicação, a que sustenta as práticas de pesquisa administrativa e a vertente crítica, são saberes modernos por excelência. Mesmo ao constatar a coisificação do homem pela técnica, a perspectiva crítica prescinde da orientação dada pelo projeto moderno quanto à razão como fator de emancipação. Convencionalmente a leitura que se faz destas posições é caracterizada por um antagonismo que pode ser traduzido em termos de perspectivas políticas opostas. O funcionalismo seria uma concepção positiva da sociedade que investe no laissez faire laissez passer do liberalismo, reproduzindo assim sua ideologia ao interrogar os processos de comunicação na sociedade segundo uma perspectiva que se concentra no fundamento do livre fluxo de mercadorias como modelo para a circulação da informação. $O$ que importa neste contexto funcionalista é otimizar tecnicamente o processo de circulação das mensagens de maneira que a própria sociedade operaria as regulações pelas quais mantém o seu equilíbrio. A comunicação é vista como um elemento articulador deste processo pelo qual se mantém a ordem estabelecida pelo sistema. A metaestabilidade funcional das forças sociais é garantida pelas práticas de comunicação que asseguram a permanência da herança cultural através da vigilância constante de tudo aquilo que possa se apresentar como uma perturbação da ordem vigente de relações sociais. O funcionalismo é ahistórico e reacionário em termos políticos e positivista em sua perspectiva sociológica. É uma teoria sistêmica a serviço da manipulação e da persuasão como instrumentos de controle social. Existe no funcionalismo uma assimilação da idéia de imanência do sistema de relações sociais, cabendo às técnicas de comunicação investirem na funcionalidade do todo. É por esta imagem de imanência que o funcionalismo converge para as relações éticas que sustentam o capitalismo, 
tal como estas analisadas por Max Weber em "A Ética Protestante e o Espírito do Capitalismo". Ao introduzir a idéia de acese intramundana, segundo Weber, o protestantismo preparou as bases pelas quais o capitalismo se desenvolveu de forma otimizada em países que adotavam essa orientação religiosa. O lucro e o sucesso no trabalho são recompensas pela fé afirmada de um ponto de vista estritamente individual. Este valor ético perpassa o funcionalismo no sentido de seu aspecto individualizante, seja em relação ao modelo hipodérmico, seja em relação à desconsideração dos fatores que incidem sobre o processo da comunicação para além de sua dimensão técnica. A escola crítica frankfurtiana ainda resguarda uma imagem de transcendência do processo, que não é visto como um fim em si mesmo, mas como reflexo de uma conjuntura estrutural própria do capitalismo.

\section{Para além do Funcionalismo e da Escola de Frankfut}

Como vimos, estas duas posições marcam a emergência do campo dos estudos e pesquisas em comunicação. As escolas e movimentos que sucederam esta dicotomia inicial tentaram cada uma a sua maneira articular métodos e respostas diferentes para a fratura originária. O estruturalismo buscou no ferramental da lingüística e das ciências da linguagem um aparato que pudesse dar conta de explicar os processos de comunicação a partir da leitura dos mecanismos pelos quais as mensagens dos meios de comunicação constroem ideologias. A obra estruturalista modelo desse tipo de abordagem é "Mitologias" de Roland Barthes. Os estudos culturais buscaram relativizar o niilismo frankfurtiano desconstruindo o poder exagerado creditado aos meios de comunicação com um cruzamento das considerações de Gramsci sobre as relações entre culturas de resistência e culturas hegemônicas (característica que reverbera a historicidade dessa vertente constituída exatamente no 
momento de eclosão da contracultura na década de 60). A recepção pela primeira vez é abordada plenamente como um elemento ativo na comunicação, que transforma as injunções da ideologia dominante veiculada pelos meios através das práticas sociais. O cotidiano é visto como um espaço de resistência que re-significa as mensagens.

Quando se coloca em questão um possível esgotamento da grande narrativa iluminista, apontada por Lyotard ${ }^{10}$ como sinal da emergência da pósmodernidade, a todas estas problematizações do campo da comunicação somase a potência de uma crise dos modelos pelos quais convencionalmente se orientam as pesquisas em comunicação. Os recentes choques provocados pelas novas tecnologias são índice desta crise. É a própria tecnologia que se torna o lugar do debate teórico, como uma mediação em sua plena potência.

Por pós-modernidade pode-se entender uma certa abordagem dos fenômenos sócio-culturais que parte de uma contextualização histórica na qual não é mais de reconhecimento imediato o primado da razão emancipatória. Ao saturar suas contradições, a própria modernidade entra em colapso e os saberes mudam de estatuto, pois não são mais unificados por um valor unívoco que os integra num projeto. Estabelece-se uma ordem imanente do mundo que encontra sua expressão histórica nos discursos da globalização. Numa realidade pós-Guerra Fria, as relações macro-estruturais passam a integrar uma ordem sistêmica ainda mais profunda e determinante do que a ideologia liberal clássica poderia acreditar.

$\mathrm{O}$ neoliberalismo não dicotomiza com nenhum outro termo. Fredric Jameson analisa o contexto pós-moderno segundo uma concepção de que o econômico converteu-se em cultural ${ }^{11}$. O capitalismo tardio se reproduz

\footnotetext{
${ }^{10}$ LYOTARD. A condição pós-moderna

${ }^{11}$ JAMESON, Fredric. Pós-modernismo - a lógica cultural do capitalismo tardio. SãoPaulo, Ática, 1996.
} 
segundo uma lógica de produção cultural. O fluxo do capital especulativo nas bolsas de valores é a imagem desse processo. Um capital que não mais está atrelado à produção. Um capital parnasiano, etéreo e volátil, quase espiritual, que reproduz a si mesmo tal qual um vírus que infecta mercados. As relações sociais resultantes desse modo de organização da produção no capitalismo tardio dão à pós-modernidade seu caráter não mais dicotômico, mas paradoxal. Diante de uma ordem imanente totalizante como a perpetrada pelo capital especulativo, os condicionantes das relações sociais não seguem mais as grandes promessas das grandes utopias. O cotidiano e o tempo presente são os novos valores que sedimentam as relações sociais. Não mais a razão, mas os sentidos, a fruição e o prazer como elementos pelos quais se estabelece não mais um grande projeto coletivo unificador, mas um estar-junto hedonista. As tecnologias da comunicação se tornam um elemento pelo qual a subjetividade pós-moderna advém. Não mais a cultura mediada pela técnica como na crítica frankfurtiana, mas a subjetividade que se produz nos agenciamentos tecnológicos pelos quais se formam novos modos de socialidade. Diante dessa perspectiva, o campo das ciências da comunicação se depara com a necessidade de novos questionamentos. As tecnologias da comunicação no contexto sócio-cultural do debate da pós-modernidade representam um condicionante que traduz a invasão do imaginário pelo tecnológico. A tecnologia neste contexto se torna fundante. Alguns críticos apontam exatamente a contracultura como o momento no qual emerge historicamente o questionamento da tecnologia como investimento da técnica pelo poder político consubstanciando a tecnocracia como nova ordem hegemônica dentro do capitalismo.

$\mathrm{Na}$ contemporaneidade a pesquisa em comunicação se orienta por uma abordagem marcada pela mestiçagem de métodos que lida com objetos 
híbridos. Isto porque a pós-modernidade também pode ser entendida como a incapacidade de uma axiologia dicotômica que ainda era possível na modernidade. A dicotomia sujeito objeto dá lugar a uma assimilação pela qual o sujeito é entendido como instável, produzido pela sua relação com o objeto, portanto assujeitado a ele - não mais como coisa pensante, res cogitans, mas como coisa desejante, um produto de suas relações com o mundo. Assim se passa da ideologia ao simulacro, porque a lógica não é mais de persuasão, mas de sedução. O sentir se rebate sobre o entender. Não há mais promessas nem horizontes, mas um pulsar do desejo que é afetado por aquilo que é desejado. Assim como Armand e Michélle Mattelart concluem em seu livro sobre a história das teorias da comunicação:

"A era da chamada sociedade da informação é também a da produção de estados mentais. É preciso pensar de maneira diferente, portanto, a questão da liberdade e da democracia. A liberdade política não pode se resumir no direito de exercer a própria vontade. Ela reside igualmente no direito de dominar o processo de formação dessa vontade. "12

Compreender o processo de formulação das vontades na sociedade contemporânea, isto é, algo das dinâmicas próprias do desejo em sua relação com as dinâmicas da informação, é algo que se inscreve no plano de uma abordagem direcionada para o horizonte conceitual de Deleuze e Guattari como veremos no capítulo a seguir.

\section{A interpelação do consumo e o sujeito pós-moderno}

Podemos então localizar essa problemática a partir de uma discussão sobre o estatuto do desejo na perspectiva de um sujeito que se depara com a passagem de um mundo moderno para um pós-moderno. Esse sujeito pós-

\footnotetext{
${ }^{12}$ MATTELART, Armand e Michélle. A História das Teorias da Comunicação. São Paulo, Loyola, 1999. p.187.
} 
moderno é o que se apresenta sob a máscara do consumo como forma definitiva de sociabilidade que encerra a história ${ }^{13}$. Não mais aquele sujeito histórico que o marxismo reconhecia no proletariado - sujeito como potência histórica -, mas a negação do histórico que se realiza na ideologia do consumo sem fim. O eterno retorno da mercadoria como a definição fatal da lei do desejo. Interpelação intransponível de uma ordem sobrecodificante - é o que, por exemplo, tentam demonstram as leituras de Joseph Heath e Andrew Potter $^{14}$. É nessa perspectiva também que Christopher Lash aponta para uma crise da modernidade que se detecta a partir do individualismo sintomático que emerge da década de 70 e se consolida na década seguinte ${ }^{15}$. Tomemos então o significado da modernidade como o que torna reconhecível aquilo que para Freud se chama civilização, ou seja,

“ (...) a soma integral das realizações e regulamentações que distinguem nossas vidas das de nossos antepassados animais, e que servem a dois intuitos, a saber: o de proteger os homens contra a natureza e o de ajustar os seus relacionamentos mútuos." 16

Civilização para Freud é o resultado do processo que os frankfurtianos vão chamar de esclarecimento. Assim como Adorno e Horkheimer, Freud também encontra na meta-narrativa iluminista o fundamento de sua concepção antropológica: a razão é a imagem da transcendência do homem sobre o estado de natureza. Em primeiro lugar em relação a si mesmo, a partir do cogito cartesiano, no domínio das paixões e pulsões e, em segundo lugar,

\footnotetext{
${ }^{13}$ O homem terminal que salta para a eternidade de um império consumado, que consome com aprópria história e que se enuncia através do discurso de Francis Fukuyama.

${ }^{14}$ Heath e Potter analisam as contradições da militância política no capitalismo tardio em livros como Rebel Sell e Nation of Rebels - Why Counterculture Became Consumer Culture. Amb oscentrados na idéia do estilo pessoal como a mais refinada forma de mercadoria a disposição dentro da lógica cultural do capitalismo tardio - tão refinada que inverte a própria idéia de crítica ao consumo em uma commodity domesticada pela indústria fonográfica, editorial, moda, cinema, etc.

${ }^{15}$ LASH, Christopher. O Mínimo Eu. São Paulo, Brasiliense, 1984.

16 apud SANTOS, Adriana Barcelar Leite E.. Os Meios de Comunicação como Extensões do Mal-Estar. Rio de Janeiro, Mauad, 2002, p.27.
} 
como instrumento através do qual o homem dominaria as forças da natureza sua redenção através da técnica. Tanto os frankfurtianos quanto Freud são essencialmente modernos.

Dessa maneira podemos então construir o seguinte conceito de pósmodernidade: o conjunto dos sintomas detectados como esgotamento de determinados aspectos da narrativa racional iluminista e que não apontam para uma outra teleologia. Em termos psicanalíticos a pós-modernidade é um complexo que se instala na modernidade a partir de sua condição traumática em termos históricos ${ }^{17}$. Daí uma lógica sintomática por exemplo no campo das artes e que se traduz num “estilo sem estilo", de pura citação paródica. Năo esqueçamos que a recepção da obra freudiana no Brasil decantou por uma questão de tradução "mal-estar na cultura", título original da obra de Freud (Das Unbehagen in der Kultur), em "mal-estar na civilização”. Seguindo Freud então temos que o tipo de "mal-estar" que os discursos da pósmodernidade apresentam como algo para além da modernidade já é uma de suas características intrínsecas.

\section{Do mecânico ao eletrônico - McLuhan Moderno ou pós-moderno?}

Uma caracterização melhor do contemporâneo está talvez na passagem de uma Idade Mecânica para uma Idade Eletrônica (definição de McLuhan), o que pode dar conta das transformações do estatuto do desejo na contemporaneidade. Percebe-se uma certa convergência de elementos do conceito de pós-modernidade com o de aldeia global em McLuhan - uma contração do espaço e do tempo graças a uma projeção de um sistema nervoso central global através da maneira pela qual os meios de comunicação se

\footnotetext{
${ }^{17}$ Como numa das passagens da obra de James Joyce mais citadas como exemplo de sua modernidade: " $A$ História é um pesadelo do qual quero despertar"
} 
constituem como próteses que ampliam os sentidos do homem. Tal assimilação é plausível no que tange ao processo de globalização enquanto marco da pós-modernidade no âmbito da economia política - a Web constituindo-se aqui como a imagem desse "sistema nervoso central".

O tour de force de McLuhan acontece em sua obra "Os Meios de Comunicação como Extensão do Homem" quando ele propõe, a partir de uma certa forma de argumentação que mais tarde vai ser chamada de determinismo tecnológico, que "o meio é a mensagem". Neste contexto McLuhan propõe a passagem de uma Idade Mecânica para uma Idade Eletrônica determinada pelo nascimento de uma "aldeia global". Por "Idade Mecânica" entenda-se o recorte histórico que observa no plano da modernidade um contexto no qual a técnica concretizada nos meios de comunicação se traduz num vetor centrípeto, a seja, de projeção do corpo no espaço, não ainda extensiva no sentido que McLuhan observará num momento posterior em relação à “inserção do Homem na era da eletrônica”. Aqui a extensão efetuada pela entrada na Idade Eletrônica projeta o sistema nervoso central numa escala global. A Idade mecânica corresponde à Primeira Revolução Industrial, essencialmente a do vapor e das estradas de ferro. A era dos transportes.. À Idade Eletrônica corresponde uma contração do espaço e do tempo que transforma o mundo numa aldeia - é o sentido oposto ao da projeção anterior. Nesse movimento de contração a tendência apontada por McLuhan é de que os meios frios (telefone, televisão e computador) passem a prevalecer sobre os quentes (rádio, jornal). Os meios passam a funcionar como próteses dos sentidos do homem - se a Idade Mecânica projetou o corpo no espaço, a Idade Eletrônica projetou a inteligência e a percepção do homem no espaço-tempo:

"Agora, é como se o mundo, os mistérios do mundo e os mistérios do sujeito estivessem ao alcance de todos, a partir 
de um simples telefonema, de um e-mail ou de um cartão de crédito. Na grande maioria das sociedades contemporâneas, as promessas de felicidade são parceladas em suaves prestações" 18

\section{O capital eletrônico}

Essa visão de McLuhan tal como é captada por Adriana Bacelar Leite SANTOS $^{19}$ sugere algumas analogias com a definição de pós-modernidade de F. Jameson. Para além do esgotamento das grandes meta-narrativas que sustentaram os sonhos de transcendência do Iluminismo (Lyotard) e de uma saturação do imaginário que reconstrói um real simulado que é "mais real do que o próprio real" (Baudrillard), Jameson considera o pós-moderno como a lógica fundante da produção simbólica em que o modo de produção capitalista passa a ser definido pelo capital especulativo, transnacional, definido pelo economista belga Ernest Mandel como "capitalismo tardio". A lógica da empresa transnacional, das grandes corporações e dos grandes blocos econômicos desenha uma estrutura onde o capital não encontra mais um registro sobre a organização tradicional do estado-nação. Há, no plano do capital, como que uma passagem, uma mudança de estatuto também, tal como a de McLuhan, o capital passa de uma era mecânica para uma eletrônica. Passa-se do capital financeiro para o capital especulativo, móvel, volátil, que percorre uma rede em tempo real e que pode se concretizar a qualquer instante em qualquer parte do mundo. O capital especulativo e transnacional é uma forma de capital que contrai o espaço assim como a projeção do "sistema nervoso central global" pelos novos meios de comunicação. Também transforma o mundo numa mônada eletrônica, numa aldeia global. O capital especulativo é a nova forma de capital traduzida pela entrada na Idade

\footnotetext{
${ }^{18}$ Op.cit.p50.

${ }^{19}$ Op.cit.
} 
Eletrônica - não mais a imagem do lastro em ouro da moeda circulante, mas apenas um impulso elétrico a mais percorrendo um sistema em rede global. Capitalismo tardio (late capitalism) no sentido de o mais adiantado no tempo, o último capitalismo, em que no movimento definido por Marx de uma reformulação constante de suas bases, o capital se torna o fundamento definitivo de si mesmo. Capital que produz mais capital. Um capital que se especula, que se dobra na imagem de si mesmo e não mais sobre um referente concreto de produção que lhe marca uma origem. A terceira idade do capitalismo em que os modelos monopolista e financeiro sucumbem diante da imagem especulativa (do latim spek do qual deriva o termo especles $=$ aparência, espetáculo e fantasma ao mesmo tempo ${ }^{20}$ ) que os arrebata tal qual o destino trágico de Narciso quando este se enamora de si mesmo. A terceira idade do capital, mas também, semioticamente, a terceiridade dele também, no sentido peirciano do termo. O capital se torna símbolo porque ele é a síntese da inteligibilidade da cultura contemporânea. Aliás, como propõe Jameson, o capital mesmo se converte no cultural, sua lógica passa a ser simbólica e não mais meramente abstrata, pois seu alcance se concretiza historicamente na cultura enquadrada pelo consumo. Qualquer outro sentido se perde diante da auto-referencialidade do consumo. É esta a extensão do mal-estar num contexto pós-moderno: a imanência de uma angústia intransponível porque não lhe é dado o direito de se perceber enquanto tal. Uma angústia gerada pela impossibilidade do sujeito pós-moderno em reconhecer-se em qualquer outra coisa que não seja o consumo. A mercadoria redobra a interdição ao gozo do objeto da qual fala Lacan. O valor abstrato da mercadoria, ou seja, o seu valor de troca, apaga o que o desejo persegue como um valor de uso reconhecido em seus objetos parciais. $\mathrm{O}$ objeto do desejo traduzido em mercadoria se torna

${ }^{20}$ Definição segundo o Dicionário Houaiss da Língua Portuguesa - versão eletrônica 1.0. 
mero objeto, coisa apartada do sujeito desejante. O desejo do sujeito pósmoderno é um desejo coisificado porque este não o reconhece mais como uma falta, uma falha impossível de ser completada. Como analisa Adriana Bacellar Leite e Santos:

"Dessa forma, o sujeito - acuado pela sua precariedade
financeira e psicológica - entra cada vez mais na solidão do
mal-estar, e se confronta com aquilo que a mídia tenta, a todo
custo, esconder ou aproveitar e transformar em mais um
produto da moda: a falta que marca inexoravelmente a
existência de todo ser humano, razão primeira de sua
inscrição no mundo da linguagem e do seu desejo." 21

É então pela própria concepção de desejo que uma crítica às contradições da sociedade contemporânea deve começar. "Os revolucionários esquecem, freqüentemente, ou não querem reconhecer que se quer e se faz a revolução por desejo, não por dever, ${ }^{22}$. Uma crítica que construa armas com as quais combater a colonização da subjetividade pela lógica do consumo. Se esta questão no contexto pós-moderno se torna instrumento de interpelação dos sujeitos segundo uma ordem tecnocrática, é então necessário buscar instrumentos para recolocar o desejo de outra maneira. Uma referência fundamental neste debate, como já o colocamos, é o pensamento de Deleuze e Guattari, isto porque já em sua primeira obra, O Anti-Édipo, é elaborada, como o próprio nome anuncia, uma crítica voltada para a psicanálise e sua correlativa imagem do desejo como falta.

Numa perspectiva nietzschiana, o Anti-Édipo é um libelo contra toda e qualquer concepção de desejo fundamentada na falta. Ao contrário do drama familiar constantemente re-encenado por um inconsciente tal como num palco teatral, os autores constroem toda uma concepção construtivista do

\footnotetext{
${ }^{21}$ Op. Cit. p.93.

22 DELEUZE, Gilles e GUATTARI, Félix. O Anti-Édipo. Rio de Janeiro, Imago, 1976. p.437.
} 
inconsciente, no qual o desejo é uma força produtiva de atualização de virtualidades, como explica Christian Deschamps:

"O que é o desejo? É uma idéia bem simples, como todas as grandes idéias. Ele ordena as coisas que virtualmente já existiam, fazendo com que tenham acesso a uma realidade, a uma nãoindiferença social, sexual, politica... [...]

[...] Inicialmente, os autores quebram a relação entre o desejo e a carência. A tradição liga o desejo àquilo que está ausente, à Lei, ao proibido. Ora, depende de um arranjo no qual está incluída. Produtor, o desejo estabelece conexões, relações que não param de atravessar um real do qual jamais sente falta, já que se alimenta dele." 23

Para Deleuze e Guattari o desejo é o princípio de produção do inconsciente que está muito mais próximo da imagem de uma usina do que de um palco de teatro. Recorrendo a Kant os autores traçam coordenadas que ao mesm tempo contrapõem à imagem do desejo como falta uma imagem produtiva, como também expõem o vínculo da falta com consumo enquanto aquisição.

"De certa maneira, a lógica do desejo erra de objeto desde o primeiro passo: o primeiro passo da divisão platônica que nos faz escolher entre produção e aquisição. Logo que colocamos o desejo do lado da aquisição, temos que o determina em primeiro lugar como falta, falta de objeto, falta do objeto real. É verdade que o outro lado, o lado 'produção', não é ignorado. Foi mesmo Kant quem operou na teoria do desejo uma revolução crítica, ,definindoo como 'a faculdade de ser por suas representações causa da realidade dos objetos destas representações'." 24 (p.42)

Temos então um paralelismo da noção de desejo em relação à psique que se projeta para um contexto social, histórico enquanto princípio de produção. $\mathrm{O}$ inconsciente é produtivo e se manifesta no real que é desejado, isto é, atualizado ${ }^{25}$. Um inconsciente funcionando produtivo tem como

\footnotetext{
${ }^{23}$ DESCHAMPS, Christian. As Idéias Filosóficas Contemporâneas na França. Rio de Janeiro, Zahar, 1991. pp. 19-21.

${ }^{24}$ DELEUZE / GUATTARI. Op.cit.p. 42

${ }^{25}$ No sentido de colocado em ato
} 
princípio as máquinas desejantes, conceito delineado por Deleuze e Guattari a partir do conceito de objetos parciais de Melanie Klein.

"Atingimos então as regiões de um inconsciente produtivo, molecular, micrológico ou microfísico, que não quer dizer mais nada e não representa mais nada. A sexualidade não é mais nada. A sexualidade não é mais considerada como uma energia específica que une pessoas derivadas dos grandes conjuntos, mas como energia molecular que põe em conexão moléculas-objetos parciais (libido), que organiza disjunções inclusivas sobre a molécula gigante do corpo sem órgãos (numen), e distribui estados, segundo domínios de presença ou zonas de intensidade (voluptas). Pois as máquinas desejantes são exatamente isso: a microfísica do inconsciente, os elementos do micro-inconsciente. Mas, enquanto tais, elas não existem nunca independentemente dos conjuntos molares históricos, das formações sociais macroscópicas que constituem estatisticamente. É nesse sentido que só há o desejo e o social." $" 26$

Temos então que o desejo é um princípio de produção que se dá segundo um agenciamento de termos heterogêneos: um dos termos servindo de corte para o segundo termo que é cortado enquanto fluxo, com o resultado deste processo tornando-se um novo fluxo que será cortado por outro elemento e assim por diante. Sempre o inconsciente opera cortes num fluxo amorfo que é a virtualidade própria do desejo enquanto fundamento de todo o real. O real é investido pelo desejo através das sínteses conectivas. Todo desejo, portanto, remete aos agenciamentos que produz segundo um processo de articulação de seus elementos heterogêneos - fluxo / corte. Deleuze e Guattari chamam este processo de síntese conectiva (e,...,e...,e....). Se o desejo é um processo

A produção como processo excede todas as categorias ideais e forma um ciclo que se refere ao desejo enquanto princípio imanente. Eis porque a produção desejante é a categoria efetiva de uma psiquiatria materialista, que coloca e trata o esquizo como

\footnotetext{
${ }^{26}$ DELEUZE/ GUATTARI Op.cit.p232, ou também na seguinte passagem da mesma obra: "Em resumo, os objetos parciais são as funções moleculares do inconsciente.” (p.412)
} 
Homo natura. Com uma condição, todavia, que constitui o terceiro sentido de processo: não é preciso que este seja tomado como uma meta, um fim, nem que se confunda com sua própria continuação ao infinito. O fim do processo, ou sua continuação ao infinito, que é estritamente a mesma coisa que sua parada brutal e prematura, é a causação do esquizofrênico artificial, como se vê no hospital, trapo tornado autista, produzido como entidade.” (p. 19)

Toda idéia de totalidade, portanto, é externa ao processo de produção operado pelo inconsciente e só se constitui enquanto tal mediante uma interrupção do mesmo, causa determinante da figura do esquizofrênico no plano individual da psique e da desterritorialização provocada pelo capital no contexto da produção social ${ }^{27}$. Temos então que toda totalidade é artificialmente imposta ao universo das máquinas desejantes. O todo advém, é quando acontece a segunda síntese do desejo. A síntese disjuntiva é uma pausa improdutiva na proliferação das conexões constituintes das máquinas desejantes (corte / fluxo). Isto se dá no momento em que se forma uma identidade entre o produzir e o produto. Em algum momento do processo tudo para em função de um suplemento que é exterior ao processo e que sobre ele se aplaca, assim como o capital se rebate sobre o trabalho, mostrando-se como sua causa deste e não como, em verdade, consequiência direta ${ }^{28}$. Essa idéia de inspiração marxista é um dos momentos mais importantes na análise do desejo empreendida no Anti-Édipo. Ela dá conta da pulsão de morte, em termos freudianos.

Deleuze e Guattari chamam esse elemento suplementar ao processo do desejo de corpo-sem-órgãos - numa alusão direta a Antonin Artaud. Como

\footnotetext{
27 “Não acreditamos mais em uma tltalidade original, nem numa totalidade de destinação. Não acreditamos mais no acinzentado de uma insípida dialíetica evolutiva, que pretende pacificar os pedaços porque ela arredonda suas arestas. Só acreditamos em totalidades ao lado. E se encontramos uma totalidade assim ao lada das partes, é um todo dessas partes, mas que não as unifica, e que se acrescenta a elas como uma nova parte composta à parte." Anti-Édipo p. 61

${ }^{28}$ Fundamento da crítica de Marx e Engels em O Capital
} 
identidade entre o produto e o produzir podemos entender que é por esta pausa improdutiva que se reconhece um agenciamento - que sua totalidade, mesmo que relativa e instável, deixa-se mostrar. Um processo extendido ao infinito, isto é, uma síntese conectiva sem esta parada seria a própria esquizofrenia. Para que o desejo atualize algo, para que ele cumpra sua essência produtiva, é necessário que haja essa parada que lhe dê um contorno reconhecível do conjunto de termos heterogêneos que o formam. A produção de um corte asignificante. Mas essa totalidade se dá ao lado do agenciamento, rebatendo-se sobre ele. Corpo-sem-órgãos porque é assim que a experiência da própria subjetividade se dá - não como o somatório do funcionamento de todos os órgãos (organismo), mas como uma totalidade que se rebate sobre eles (corpo erógeno). Segundo Deleuze e Guattari o corpo-sem-órgãos é o elemento neutro de todo e qualquer agenciamento. Ele também não se dá por uma negação, mas por um limite pelo qual a proliferação da síntese conectiva tende a uma parada.

Sempre produzindo a partir do agenciamento entre cortes e fluxos, as máquinas desejantes são responsáveis pela produção de subjetividade. Deleuze e Guattari fixam então dois extremos entre os quais esse processo oscila: um polo esquizofreneizante, de uma conectividade sem parada, sem a possibilidade de um corte significante e que produza um sentido como recognição do processo e um outro polo neurotizante onde todo corte fecha-se sobre si mesmo, numa produção de sentidos que sempre gravita e para sobre um mesmo centro. Proliferação sem parada e parada sem proliferação são as duas situações limite a que o desejo pode tender. Não que a esquizofrenia e a neurose sejam excludentes, antagônicas. Deleuze e Guattari colocam o problema em outros termos, trata-se de abrir o inconsciente, assim como ele é entendido por certa ortodoxia psicanalítica, de uma dimensão individual 
(neurótica), para uma esfera social e política (esquizofrenia). Segundo os dois pensadores, o desenvolvimento da psicanálise como prática clínica insiste no polo neurotizante para o qual o desejo tende, isto é, relaciona-o demasiadamente ao indivíduo em detrimento das forças políticas e históricas que produzem as subjetividade em um determinado momento histórico.

A crítica central do Anti-Édipo diz respeito à uma reorientação do conceito de inconsciente para o plano coletivo, não em termos Jungnianos, que não equacionam sua dimensão política, mas numa perspectiva mais convergente com o pensamento de Reich. As massas desejam a própria história. A história como resultado de um processo de produção coletiva assim também como todo delírio enquanto expressão histórica e coletiva. É para atingir essa dimensão político coletiva do inconsciente que Deleuze e Guattari propõem um direcionamento para o polo esquizofrenizante do delírio porque nele se revela o funcionamento das máquinas desejantes. Uma máquina miraculante que produz um corpo-sem-órgãos, uma totalidade paralela ao agenciamento e que se coloca sobre o mesmo de tal maneira que faz parecer com que o processo de produção fosse efeito e não causa da formação desta máquina - daí ela ser "miraculante" (síntese conectiva), por essa gravidade e atração. Mas ao mesmo tempo existem forças no interior do agenciamento como dispersão - fruto dessa segunda síntese do desejo: a síntese disjuntiva. Nela pode acontecer das máquias desejantes serem arrombadas sobre o corposem-órgãos e passarem a ser decodificadas como clandestinas, como uma ameaça à própria subjetividade: é quando se forma uma máquina paranóica. Rompe-se a possibilidade de uma recognição dos termos do agenciamento. A anorexia (hesitação entre um orifício que serve para a entrada de alimentos e outro que cumpre a função de expelir o resultado da digestão dos mesmos) curto-circuito no sistema todo. 
A essas duas sínteses, Deleuze e Guattari acrescentam uma terceira e última, uma síntese conjuntiva, que forma uma máquina celibatária. Isto no sentido de que ao seguir o agenciamento maquínico do desejo chega-se a uma linha de pura abstração, a uma máquina abstrata para qual todo o desejo tende e que é a própria virtualidade que percorre o processo todo. É por essa máquina abstrata que se chega à esquiza. A esquiza é essa linha abstrata que serve de linha de fuga para todo o sistema englobado no agenciamento maquínico. Linha de fuga porque é por essa possibilidade aberta pela esquiza que algo escapa em direção ao pólo esquizofreneizante a partir do qual o agenciamento seja aberto para o histórico, social, coletivo, em suma. Para Deleuze e Guattari “fluxo-esquizo" é o contrário da esquizofrenia. Nesta, todos os sentidos deslizam sem a possibilidade de um corte significante. $\mathrm{O}$ “fluxo-esquizo" é a possibilidade assegurada de trânsito com essa linha de fuga, com e através da esquiza. Pela abstração o agenciamento escapa aos sentidos codificados. Há, como chamam Deleuze e Guattari, uma desterritorialização, isto é, um apagamento da delimitação dos sentidos dados segundo os códigos instituídos. Na esquizofrenia os limites impostos pelo sentido são completamente apagados, sem a possibilidade que um corte possa gerar um novo sentido. Tudo desliza num puro fluxo em direção ao FORA da linguagem - a um puro campo de sentidos em aberto. O " fluxo-esquizo" não se comporta dessa maneira. Ele é um investimento do desejo sobre o campo imediatamente social político e econômico. É o fluxo esquizo que faz com que algo escape aos códigos. Ele desterritorializa. Sempre. A vida nômade sobre as linhas de fuga.

A arte trabalha essencialmente com as linhas de fuga. Com a literatura não é diferente. Em certo sentido, uma poética nada mais é do que a montagem de uma máquina de escrita com um plano de se atingir a esquiza, a 
linha de fuga pela qual toda a linguagem assume um devir minoritário. Isto é, a linguagem passa a dar voz ao que lhe é menor, aos sentidos que são uma virtualidade em seu interior mas que ficam obstacularizados pelas codificações e territorialidades do estabelecido, do já codificado. Se a poesia é, antes de tudo, um processo de construção de novos sentidos, de produção portanto, ela trabalha necessariamente com uma desterritorialização da linguagem. Vamos então em direção a uma poética do jornalismo. 


\section{Para trair o jornalismo}

"Não cabe temer ou esperar, mas buscar novas armas."
Gilles Deleuze em
"Post-Scriptum Sobre as Sociedades de Controle"

O que move este trabalho é o desejo de uma espécie libertária. Um desejo que não se satisfaz com uma prática jornalística dada, de contornos rigorosos e devidamente registrada na superfície dos grandes poderes instituídos. É a paisagem que se insinua em direção ao horizonte de um jornalismo que está por vir. Pensar o jornalismo a partir dos pontos pelos quais ele se desconhece. Inventar um jornalismo assim como Nietzsche propunha escrever para um povo que virá, porque ainda está para ser criado e, escrever, portando, passa a ser um ato fecundo, ou melhor, de fecundação, assim como uma vespa se torna parte do aparelho reprodutor de uma orquídea. Além de Nietzsche, um herdeiro especial de seu legado é quem vai servir aqui de referência nesse exercício de articulação do possível: Gilles Deleuze, especialmente em sua produção a quatro mãos com Félix Guattari.

Talvez nenhum outro pensador contemporâneo tenha se colocado tão frontalmente contrário às práticas da mídia quanto Gilles Deleuze. Daí uma possível justificativa para essa sutil lacuna que começa aos poucos a ser preenchida com relação à acolhida de seu pensamento em meio à pesquisa em comunicação.

A aversão à mídia foi característica da démarche deleuziana, mas em alguns momentos de sua obra algo escapa como uma linha que aponta para 
outros possíveis, como nesta passagem onde Deleuze em conjunto com a jornalista Claire Parnet propõe uma inversão da lógica da informação:

O esquema da informática parte de uma informação teórica supostamente máxima; no outro extremo ela coloca o barulho como ruído, antiinformação, e, entre os dois, a redundância, que diminui a informação teórica, mas lhe permite também vencer o barulho. Ao contrário, seria assim: no alto a redundância como modo de existência e de propagação das ordens (os jornais, as "notícias" procedem por redundância); em baixo, a informação-rosto como sendo sempre o mínimo requerido para compreensão das ordens; $e$, mais embaixo ainda, algo que poderia ser tanto um grito quanto silêncio, ou a gagueira, e que seria como a linha de fuga da linguagem, falar em sua própria língua como um estrangeiro, fazer da linguagem um uso menor ${ }^{29}$.

Ao se representar esquematicamente a proposição de Deleuze e Parnet temos os seguintes diagramas:

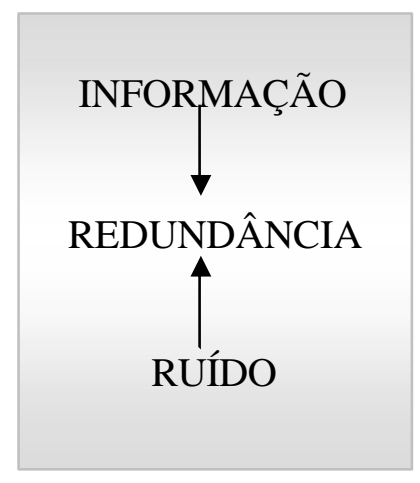

a) Modelo convencional da teoria da comunicação (modelo de Shannon e Weaver)

\footnotetext{
${ }^{29}$ DELEUZE, Gilles e PARNET, Claire. Diálogos. São Paulo, Escuta, 1998. p37
} 


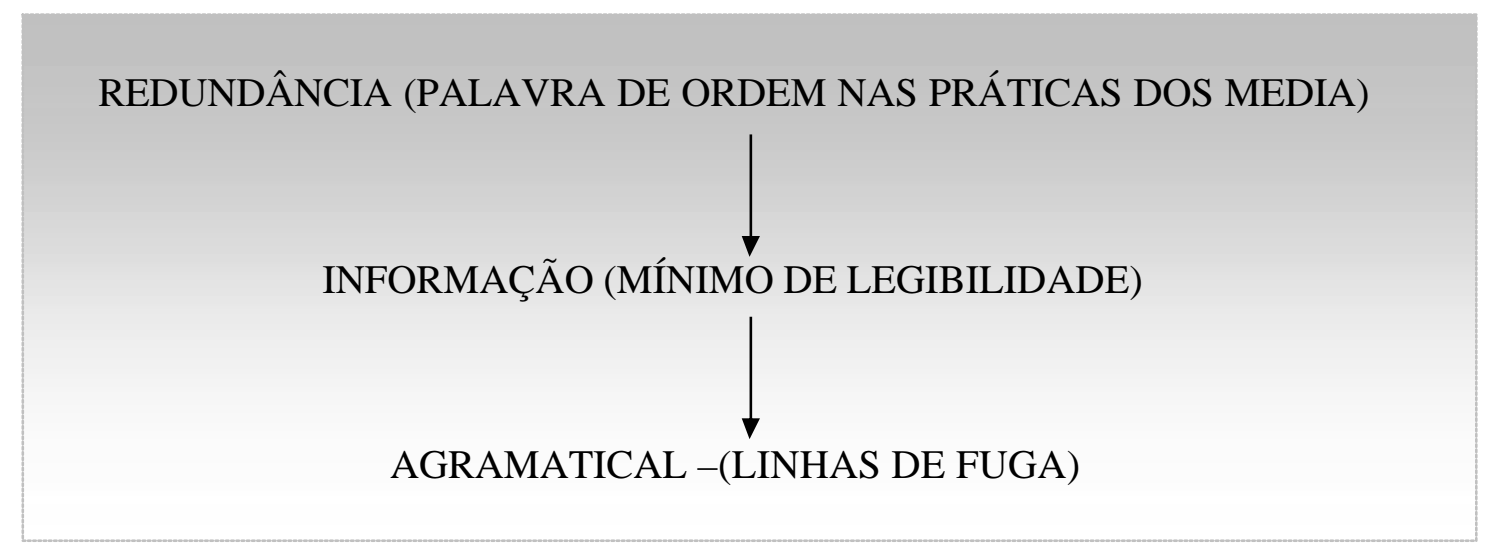

b) Modelo proposto por Deleuze e Parnet

Há algo de paradoxal nisto, pois Deleuze, em todas as vezes que foi possível, manifestou-se como um amante dos paradoxos. Foi assim que Deleuze escreveu uma obra devotada a eles: a Lógica do Sentido. Paradoxalmente também Deleuze lia diariamente as edições do Le Monde, como o filósofo assume em sua grande entrevista, talvez a única para televisão (o Abecedário Deleuziano), concedida à jornalista Claire Parnet sob a condição de ser divulgada somente em caráter póstumo. A insatisfação de Deleuze com a mídia é um indicador seguro de uma potência crítica da qual buscamos aqui nos armar, como na seguinte passagem:

"De modo que o problema consiste em reinventar não apenas para a escritura, mas também para o cinema, o rádio, a televisão, e até mesmo para o jornalismo, as funções criadoras ou produtoras liberadas dessa função-autor sempre renascente." ${ }^{30}$

Nem sempre jornalismo e literatura delimitam-se por fronteiras pacíficas. Talvez a origem do conflito esteja em um interesse comum: tal como poetas e escritores, é algo difícil de definir, mas todo jornalista que realmente gosta da profissão, antes de qualquer outra coisa gosta mesmo é da

${ }^{30}$. Ibdem. 
palavra. Do texto. E não há tecnologia que consiga soterrar isto por completo. Afinal sem texto não há notícia, seja lá qual for o tipo de mídia que ainda se invente. Porque o jornalismo é uma arte do efêmero, contudo, essa devoção ilimitada pela palavra pode vir a constituir, a partir de um jornalista, um autor. Talvez o ideal da profissão seja arrancar assim algo do tempo. Roubar prometeicamente o fogo da literatura. Todo jornalista pode se tornar um bandido santificado, como Paulo Leminski definia a si mesmo, "um bandido que sabia latim”. Todo jornalista pode se tornar um Robin Hood que partilha com o gentio o resultado de seus assaltos em domínios estrangeiros, um Prometeu. Todo jornalista pode se tornar um autor. Se em determinado momento da teoria literária se discutiu a "morte do autor", aqui, no contexto do jornalismo é tempo de anunciar o seu nascimento. Como ser marginal que é, um jornalista-escritor é temido e execrado como traidor. Em qualquer dos sentidos que se construa essa relação, jornalista-escritor ou escritor-jornalista, o resultado é a obra de um outsider.

É que trair é difícil, é criar. É preciso perder sua identidade, seu rosto. É preciso desaparecer, tornar-se desconhecido. ${ }^{31}$

Um estilo, uma dicção, uma força de expressão inclassificável a não ser por uma categoria que possa dar conta de uma singularidade explosiva. Por que não pensar então num contra-modelo próprio dessa legião de proscritos, de desertores? Desses homens de guerra? Desses traidores jamais trapaceiros:

"Traidor do mundo das significações dominantes e da ordem
estabelecida. É bem diferente do trapaceiro: o trapaceiro pretende
se apropriar de propriedades fixas, ou conquistar um território, ou,
até mesmo, instaurar uma nova ordem. O trapaceiro tem muito
futuro, mas de modo algum um devir. O padre, o adivinho, é um
trapaceiro, mas o experimentador, um traidor. O homem de Estado

${ }^{31}$ Ibdem p.58 
ou homem de corte, é um trapaceiro, mas o homem de guerra (não marechal ou general), um traidor." 32

Como então trair o jornalismo no sentido deleuziano em questão? Explorar as possibilidades de uma experimentação a partir de materiais com os quais compor um problema: uma das mais sublimes traições ao jornalismo, o new journalism. A tênue linha que separa o gênio do impostor, um estilo no jornalismo do mero sensacionalismo, o traidor do trapaceiro, tal como Deleuze e Parnet definem.

Não se resume então a um padrão de mercado as possibilidades da linguagem empregada no jornalismo. De acordo com o modelo de inversão da lógica da informação, tal como foi apresentado acima no diagrama construído a partir das colocações de Deleuze e Parnet, dois pólos atraem a informação para potências essencialmente distintas: a que prevalece largamente como determinada pelas exigências mercadológicas de massa, que trabalha por redundância e, assim, assenta e estabiliza sentidos que dizem respeito a uma certa ordenação do mundo segundo parâmetros fixos. Por outro lado, talvez de forma menos perceptível, porque na contramão dessa demanda, uma outra possibilidade de linguagem com características movediças, variáveis, intensivas e que se coloca como dinâmica própria dos acontecimentos projetada para dentro da linguagem jornalística mesma. A historicidade dessa linguagem, logo, sua singularidade. Sua linha de fuga. Existem momentos na constituição histórica da prática jornalística que se definem por esta singularidade. Por um estilo. Ao contrário da perspectiva oposta, de um investimento sobre a linguagem segundo uma concepção mimética e de correspondência especular com o real, o pólo dinâmico da linguagem jornalística investe assim o valor da diferença. É o caso exemplar das linhas de

\footnotetext{
${ }^{32}$ DELEUZE, Gilles e PARNET, Claire. Diálogos. São Paulo, Escuta, 1998. p.54-55.
} 
fuga que se abriram no tipo de jornalismo que se constituiu a partir do fenômeno da Contracultura e que ficou conhecido como New Journalism.

Por Contracultura entenda-se o enquadramento das forças político culturais que confluem para uma crítica da tecnocracia e do controle social resultante desta na sociedade industrial. Roszak situa este enquadramento como um plano que começa a se expandir a partir do conflito de gerações que se estabelece na América do período pós-guerra. Segundo o sociólogo, a Contracultura surge a partir do desencanto com o modo de subjetivação dominante no pós-guerra americano, o chamado american way of life.

"O que a transição de gerações a que estamos assistindo tem de especial é a escala em que ela está ocorrendo e a profundidade de antagonismo que ela revela. Na verdade, quase não parece exagero chamar de 'contracultura' aquele fenômeno que estamos vendo surgir entre os jovens. Ou seja, uma cultura tão radicalmente dissociada dos pressupostos básicos de nossa sociedade que muitas pessoas nem sequer a consideram uma cultura, e sim uma invasão bárbara de aspecto alarmante. "33

Existe uma causa sociológica para tal fenômeno de emergência da polaridade de gerações no debate político: uma bolha demográfica que irrompe na década de 50 é a causa do baby boom - um substancial aumento nas projeções demográficas de uma população jovem que passa a ser a base desta mesma sociedade. É sobre o plano sociológico desse incremento da população jovem do pós-guerra que vai germinar uma forma de cultura, a princípio, não fundamentada nas bases institucionais que garantem a estabilidade da tecnocracia. Esta é a dimensão que reúne então sobre o conceito de contracultura manifestações como a beat generation, a nova esquerda, a imprensa underground e o movimento hippie: a rejeição dos valores que fundamentam a tecnocracia. Para Roszak a tecnocracia vem a ser

\footnotetext{
${ }^{33}$ ROSZAK, Theodore. Petrópolis, Vozes, 1972. p.54
} 
a forma pela qual se institui uma ordem social fundamentada no controle desta através da técnica.

"Quando falo em tecnocracia, refiro-me àquela forma social na qual uma sociedade industrial atinge o ápice de sua integração organizacional. É o ideal que geralmente as pessoas têm em mente quando falam de modernização, atualização, racionalização, planejamento. (...)

(...) Chegamos assim à era da engenharia social, na qual o talento empresarial amplia sua esfera de ação para orquestrar todo o contexto humano que cerca o complexo industrial. (...)

(...)Na tecnocracia tudo aspira a tornar-se puramente técnico, objeto de atenção profissional. Por conseguinte, a tecnocracia é o regime dos especialistas - ou daqueles que podem empregar os especialistas. Entre suas instituições mais basilares encontramos os centros de prospectiva, uma indústria de muitos bilhões de dólares que procura prever e integrar no planejamento social absolutamente tudo. ${ }^{34}$

A tecnocracia pode ser entendida como a racionalidade de um poder assentado sobre um saber técnico, logo especializado, o qual concebe a sociedade como uma positividade passível de ser administrada segundo as determinações deste saber especializado. É o poder que coloca em curso uma engenharia social. Segundo Roszak a tecnocracia se constitui num nível subjacente ao debate entre a direita e a esquerda políticas. Ambas as orientações políticas competem entre si no plano ideológico, mas este antagonismo mesmo não deixa de sugerir um falso movimento, no sentido de que a projeção da qual se constitui este nível ideológico permanece intacta:

"Na tecnocracia, tudo deixou de ser pequeno, simples ou fácil de entender para o homem não-técnico. Pelo contrário, a escala e a complexidade de todas as atividades humanas - no campo político, econômico e cultural - transcende a competência do cidadão amadorista e exige inexoravelmente a atenção de peritos possuidores de treinamento especial." 35

\footnotetext{
${ }^{34}$ Op. cit. p. 19-20.

${ }^{35}$ Ibdem.
} 
A rejeição às injunções da tecnocracia pela cultura jovem da transgressão, a contracultura portanto, marca o nascimento de uma linha de ruptura com valores fundamentalmente modernos, já que amparados por uma base que lhes é dada pela razão como valor transcendente. "Liguem-se, sintonizem-se e caiam fora" ${ }^{\text {, }}$, dizia Thimoty Leary. A contracultura foi, segundo Roszak, a emergência de um discurso pautado por contra-poderes não intelectivos. Podemos entender tais contra-poderes então como sendo da ordem da intensidade. Se a racionalidade moderna converteu-se na esmagadora tecnocracia que aliena o indivíduo cabe então opor a esta ordem uma forma de conhecimento que seja inapropriável - um saber subjetivo que só pode ser definido como intensivo, não-objetivo. Saber que nasce portanto de uma ruptura com a racionalidade mesma que institui e distribui o poder entre a esquerda e a direita. É desta maneira que a contracultura desenha para si um plano intensivo. Não dialético; não axiológico. Portanto a contracultura se desenvolve no que Deleuze e Guattari definem como sendo um espaço liso, em contraposição ao espaço estriado. Esse par conceitual delineado num dos platôs deleuzo-guattarianos foi desenvolvido a partir de uma idéia de Pierre Boulez, formulada a respeito de sons que são imediatamente reconhecidos dentro de uma composição como sendo sons musicais - o que determina um espaço estriado portanto, em que cada som tem um valor musical imediatamente reconhecível, convencional segundo a semiotização dominante do código musical - em contraposição, há um outro tipo de espaço que é próprio da nova música, um espaço de sons que não são imediatamente reconhecidos como musicais pois se desenvolvem num espaço liso onde as identidades fixas são substituídas pelas intensidades nômades.

36 "Turn in, tune on and drop out" 
Podemos pensar este novo valor intensivo que a contracultura cria para si como uma linha de fuga das potências fixas que a tecnocracia estabelece ao estriar o social. É este o plano político da contracultura: drop out, literalmente "cair fora", fugir. Não no sentido de uma fuga do mundo, mas exatamente o contrário. "A linha de fuga é uma desterritorialização" ${ }^{37}$. É a "aquisição de uma clandestinidade". Coloca-se numa linha de fuga todo aquele que proustianamente escreve em sua própria língua como se escrevesse numa língua estrangeira. Uma linha de fuga é uma linha que leva ao deserto. A fuga aqui é uma deserção das potências fixas. Quem se coloca sobre uma linha de fuga não é um trapaceiro, mas um traídos, não um fugitivo mas um desertor: aquele que se dirige para o deserto, espaço de desterritorialização absoluta. Muhammed Ali traça uma linha de fuga ao desertar diante de sua convocação para o Vietnã. Não somente pela recusa em reconhecer a legitimidade de sua convocação, mas sobretudo por traçar uma linha de ruptura que desterritorializará os valores da sociedade tecnocrática que o recrutaram em vão. Uma linha de fuga é esta forma de ruptura.

"Uma verdadeira ruptura pode se estender no tempo, ela é
diferente de um corte significante demais, ela deve ser
continuamente protegida nâ apenas contra suas falsas
aparências, mas também contra si mesma, e contra as
reterritorializações que a espreitam. „38

Deleuze define assim o que vem a ser uma linha de fuga coincidentemente num ensaio em parceria com Claire Parnet o qual tem como título "Da Superioridade da Literatura Anglo-Americana". Nele Deleuze traça a segmentariedade da linha de fuga que vai de Mellville a Jack Kerouac, linhagem que faz da literatura anglo-americana "superior" por ser uma

\footnotetext{
${ }^{37}$ DELEUZE, Gilles e PARNET, Claire. Diálogos. São Paulo, Escuta, 1998.

${ }^{38}$ Op.cit. p.52.
} 
literatura de ruptura com as potências fixas. Na literatura anglo-americana prevalece a imagem de um oeste mítico, de uma terra não cartografada a ser conquistada. A segmentariedade proposta por Deleuze vai até Kerouac, o mestre de cerimônias da geração beat - o nômade errante não apenas pelas míticas travessias coast to coast, mas também nômade dentro da linguagem que passa a ter uma prosódia própria do sax de Charlie Parker que desterritorializa a prosa tornando-a música. Nem poesia nem prosa, mas algo não cartografado que se insinua como uma região a ser experimentada entre dois reinos distintos.

Estranha literatura anglo-americana: de Thomas Hardy, de Lawrence a Lowry, de Miller a Ginsberg e Kerouac, homens que sabem partir, embaralhar os códigos, fazer passar fluxos, atravessar o deserto do corpo sem órgãos. Eles atravessam um limite, quebram um muro, a barra capitalista. E certamente acontece não conseguirem o acabamento do processo, eles não cessam de não consegui-lo. Refecha-se o impasse neurótico -o papai-mamãe da edipianização, a América, o retorno ao país natal - ou então a perversão das territorialidades exóticas, e depois a droga, o álcool - ou pior ainda, um velho sonho fascista. Nunca o delírio oscilou melhor de um de seus pólos ao outro. Mas através dos impasses e dos triângulos, um fluxo esquizofrênico escorre, irresistivel, esperma, rio, esgoto, blenorragia ou fluxo de palavras que não se deixam codificar, libido demasiado fluida e demasiado viscosa: uma violência à sintaxe, uma destruição concertada do significante, não-sentido erigido como fluxo, polivocidade que volta a freqüentar todas as relações.” (p.171-172) ae

Um duplo-devir que é assimétrico. Uma intensidade que não se resolve, mas oscila como uma duração que diferencia-se de si mesma. De acordo com Roszak há uma lógica de acumulação na prosódia beat de Ginsberg e de Kerouac tanto quanto na improvisação de Charlie Parker e na action painting de Jackson Pollock. Há o apelo a uma potência não intelectiva como linha de fuga no sentido da instauração de um fluxo espontâneo de linguagem, uma desautomatização da linguagem: 
“Em lugar da revisão temos acumulação. (...)

(...) Há na obra de Ginsberg muito da improvisação de Charlie

Parker, bem como do espírito dos action painters. Jackson Pollok

trabalhava numa tela com o compromisso de nunca apagar, nunca refazer, nunca retocar, mas acrescentar, acrescentar, acrescentar... e deixar que a obra se transformasse por si só em algo de singular apropriado a este homem, neste momento de sua vida.(...)

(...) O que temos aqui é uma busca de arte que não tenha o intelecto como mediadora." 39

O grifo nosso marcado na passagem acima tem como função relacionar esta estética de acumulação, portanto de intensidade, como um processo pelo qual se produz um agenciamento, uma síntese conectiva (e... e... e... ). Segundo Deleuze e Guattari, um age nciamento é a articulação pela qual o desejo produz alguma coisa, atualiza uma virtualidade no plano do real.

Em "O Anti-Édipo", primeira obra conjunta da dupla de pensadores, é desencadeada uma inversão do conceito psicanalítico do desejo. Para Freud o desejo nasce a partir de uma falta fundamental de seu objeto pela interdição ao gozo do mesmo. Esta interdição surge a partir de um drama triangular no qual a criança percebe que o seu desejo, que encontra na figura da mãe seu objeto perfeito, concorre com o desejo do pai pelo mesmo objeto. Desse drama básico, ao qual Freud chama de complexo de Édipo, surge a lei da triangulação do desejo, que coloca este como sendo fundamentado numa falta que lhe é inerente. A partir do complexo de Édipo todo e qualquer objeto sobre o qual recaia o desejo será um objeto incompleto, marcado por uma falta. Esta falta dispara um mecanismo de compensação simbólica que é acionado pelo inconsciente, a fantasia. Segundo Deleuze e Guattari, Freud concebe o inconsciente como um palco onde se representa sempre o mesmo drama. A crítica que a dupla de pensadores faz à concepção psicanalítica do

\footnotetext{
${ }^{39}$ ROSZAK, Op. cit. p. 133-134.
} 
desejo é que ela rebate toda e qualquer triangulação sobre este drama familiar fundamental, fechando o inconsciente como uma força reativa. A inspiração do Anti-Édipo é nietzscheana ao construir uma concepção de inconsciente como sendo definido por uma força ativa, uma vontade de poder que atualiza uma intensidade. A atualização que o desejo promove é construtiva por ser definida inicialmente por uma síntese conectiva onde se formam as máquinas desejantes: máquina como princípio de agenciamento, de articulação entre um fluxo e um corte. Entre uma intensidade e um sentido que a corta e produz uma outra intensidade a ser cortada por um outro sentido e assim sucessivamente até a formação de uma pausa improdutiva dada pela saturação do processo. Ponto de máxima saturação em que se forma um Corpo Sem Órgãos - percepto de uma pura intensidade que se atualiza numa hecceidade, numa subjetivação sem sujeito, posto que este é desterritorializado pelo desejo.

Ao se correlacionar a Contracultura como fenômeno histórico com os protocolos pelos quais ela se coloca como uma linha de fuga, passamos então ao mapeamento dos agenciamentos que na cultura da mídia apontam para esta política. Uma política desejante no sentido que esta expressão assume frente a obra de Deleuze e Guattari.

No plano da cultura da mídia esses agenciamentos são construídos com materiais significantes de origem heterogênea. Desde as narrativas do new journalism e do gonzo journalism que reconstroem o cenário da contracultura numa discursividade pautada pelos mesmos valores que procura simbolizar; a pop art que busca paradoxalmente desautomatizar o olhar reciclando o lixo visual da cultura industrial; o "cinema de autor" que produz uma subjetivação polifônica na mais social de todas as artes; na estética de acumulação, como já vimos, do be-bop e da poesia visionária da beat generation; até os segmentos 
dessa linha de fuga que podemos projetar a partir do plano políticio sobre as determinações de uma sociedade pós-industrial, onde a tecnocracia se torna completamente arraigada no plano político - onde estão as brechas, os interstícios que tornam possível traçar um segmento que prolongue a linha de fuga detectada por Roszak e experimentada pela geração de 60? É possível haver um investimento revolucionário sobre o plano de relações sociais que atravessam o jornalismo? Em que pontos esse agenciamento se insinua como possível? Duas obras se enquadram nas coordenadas fixadas por estas perguntas: "Anti-Disciplinary Protest -Sixties Radicalism and Postmodernism", de Julie Stephens e "Lines of Flight - Discousive Time and Countercultural Desire in the Thomas Pynchon's Work", de Stephen Matessich $^{40}$. O primeiro é uma análise histórica e sociológica do fenômeno e o segundo uma abordagem pós-estruturalista dos estudos literários que procura reverberações da contracultura na obra do autor de Rainbow's Gravity.

Para Julie Stephens o bordão de Abbi Hoffman, "a confusão é mais poderosa do que a espada", serve de síntese do espírito contracultural que marcou a década de 60. Isto porque o chiste espirituoso do ativista político é expressão do que a autora define como política anti-disciplinar:

\begin{abstract}
"Thsi will entail an examination of what I call an 'anti-disciplinary politics', a language of protest which rejected hierarchy and leadership, strategy and planning, bureaucratic organization and political parties and was distinguished from New Left by its reidiculing of political commitment, sacrifice, seriousness and coherence. The concept of an ani-disciplinary politics refuses many of the problematic distinctions which shape the familiar paradigms of the sixties, most notably the boundary between the activist and the hippie." (p.04)
\end{abstract}

\footnotetext{
${ }^{40}$ STEPHENS. Julie. Anti-Disciplinary Protest - Sixties Radicalism and Postmodernism. Melbourne/Austrália, Cambridge University, 1998.

MATESSICH, Stephen. Lines of Flight: Discousive Time and Countercultural Desire in the Thomas Pynchon's Work. Londres e Durhan, Duke University Press, 2003.
} 
A política antidisciplinar pode então ser entendida como uma linguagem rizomática, não hierarquizante, característica não só das manifestações públicas de grupos como os diggers de San Francisco, os quais se autoproclamavam um grupo no qual todos eram líderes ${ }^{41}$. Todos os manifestos divulgados pelos diggers eram assinados sob o pseudônimo de George Medevsky - identidade imaginária coletiva do grupo. Num espectrDo mais amplo, a política antidisciplinar pode ser entendida como uma militância do non sense, como forma de desestabilização dos sentidos que se reproduzem através dos mecanismos ideológicos da linguagem. Em termos deleuzianos isto se traduz como um investimento na ruptura com as palavras de ordem. Linhas de fuga contra a redundância. Já a perspectiva explicitamente deleuziana de Mattesich em sua análise da obra de Thomas Pynchon parte da construção do conceito de desejo contracultural. Desejo de escapar às sobredeterminações do Estado, da guerra, do sexismo, do capital, enfim, fugir no sentido de traçar uma linha de fuga. Desejo contracultural e política antidisciplinar. Desejo e política. Política desejante. Deleuze e Guattari.

\footnotetext{
${ }^{41}$ Jerry Rubin, outro ativista famoso da época dizia “Todo yippies é um líder sem seguidores".
} 


\section{Deleuze e Guattari e as linhas de fuga}

Enquadrar a contracultura dentro das categorias tradicionais das ciências humanas e, principalmente, em termos de uma teoria política convencional é uma operação que incorre no risco de perder uma das características fundamentais desse fenômeno. Como já apontava Roszak em sua obra sobre o tema, o que define a contracultura é sua posição politicamente avessa a uma axiologia entre esquerda e direita. "Contra" não necessariamente significa neste caso uma atitude reativa, de mera oposição binária em relação à ordem estabelecida pelos códigos da cultura dominante. Neste sentido podemos estabelecer um parâmetro nietzschiano em torno do argumento de Roszak - caracterizar a contracultura como uma subcultura de esquerda em termos convencionais seria reconstruir o que Nietzsche chama de ressentimento: toda e qualquer forma de vínculo moral de subordinação a uma metafísica, porque assim esta ação não é a afirmação de uma potência em si mesma, mas depende de um valor pré-estabelecido para legitimar-se ${ }^{42}$. Tornase assim reativa em relação à própria potência dos acontecimentos em virtude de seu vínculo moral com uma ordem de valores entendida como transcendente. É uma forma de rebaixar a vida em sua plenitude de manifestação direta para privilegiar uma determinada imagem da vida segundo um código que a reconstrói a partir de um padrão moral. Nietzsche é o pensador do "amor fati" (amor ao destino ${ }^{43}$ ): o que interessa é a experiência

\footnotetext{
42 Em "Nietzsche e a Filosofia", Deleuze descreve a teoria das forças na obra deste pensador. Em qualquer fenômeno interagem forças ativas e forças reativas. Uma força ativa seria aquela em que a potência afirma-se a partir de si mesma. Uma força reativa é exatamente o contrário disto, ela depende de algo que lhe defina a partir de uma potência extrínseca à sua essência, daí ser reativa, em função estar separada a potência (força) daquilo que ela pode.

${ }^{43}$ Como no haikai de Paulo Leminski: "Não discuto com o destino/ o que pintar eu assino" - o bigode de Nietzsche como o sorriso do gato de Alice no rosto do poeta.
} 
direta do fluxo do puro devir que se manifesta nos acontecimentos. Quando Nietzsche fala de uma "transvaloração de todos os valores", isto remete a uma transversalidade a qualquer sistema transcendente de valoração. "Para além do bem e do mal". Nem direita, nem esquerda, mas também nem afirmação, nem pura negação. Não reconstruir o erro de rebaixar a vida significa então afirmar uma pura diferença. A vida é o que esgota os códigos a todo momento e os obriga à história - trágico fim de todos os grandes sistemas metafísicos. A vida é a imanência de uma pura diferença. O antiprograma político do espírito contracultural é o conjunto das recusas em participar do jogo das oposições binárias.

Nesse sentido, a contracultura enquanto fenômeno guarda uma série de ressonâncias com o pensamento de Gilles Deleuze e Félix Guattari. Ambos deram início a uma produção conjunta que marcou a intelectualidade francesa pós-Maio de 68. Gilles Deleuze e Félix Guattari encontram-se então inscritos no território teoricamente demarcado como pós-estruturalista. Isto significa um alinhamento com Lyotard, Foucault e Derrida. Todos como que gravitando em órbitas irregulares em torno do pai da filosofia do meio-dia: Friedrich Nietzsche.

\begin{abstract}
"A genealogia do pós-estruturalismo francês tem que ser compreendida, em parte, por suas filiações com o pensamento de Nietzsche. Em particular, com sua crítica da verdade e sua ênfase na pluralidade da interpretação; com a centralidade que ele concede à questão do estilo, visto como crucial, tanto filosófica quanto esteticamente, para que cada um se supere a si próprio em um processo de perpétuo autodevir; com a importância dada ao conceito de vontade de potência e suas manifestações como vontade de verdade e vontade de saber."44
\end{abstract}

\footnotetext{
${ }^{44}$ PETERS, Michael. Pós-Estruturalismo e Filosofia da Diferença - uma introdução. Belo Horizonte, Autêntica, 2000. p.32.
} 
O pós-estruturalismo radicaliza algumas propostas do estruturalismo se o fundamento de todo processo de significação é a arbitrariedade fundadora da relação entre signo e referente, deduz-se que em última instância as próprias estruturas remetem a um fundamento não necessário, isto é, um afundamento (em alemão abgrund, que também pode ser traduzido como abismo (literalmente "sem fundo"), daí o pensamento de Nietzsche também ser chamado pensamento do abismo, porque remete a um a-fundamento de todos os valores). Dessa maneira qualquer construção no campo das humanidades depende de uma desaceleração do fluxo do puro devir como ponto de partida, isto é, a construção de um valor de origem que é moral. Mas ao mesmo tempo para além dessa origem produzida por um ato fundador segundo uma moral nada se coloca como fixo, perene. Toda e qualquer desaceleração só é percebida como contraste em relação a este a-fundamento que suspende qualquer fixidez em nome de um puro devir que a tudo atravessa. O tema da origem moral como desaceleração do devir fossilizado em estruturas transcendentes é a intersecção do pensamento pós-estruturalista com a filosofia de Nietzsche.

Dessa maneira, pode-se afirmar que existe um pathos próprio em torno do nome de Deleuze que diz respeito a uma forma de pensamento essencialmente transgressora. Uma das possíveis razões disto é relacionada à sua geração que ficou associada aos eventos de maio de 68 na França e à Universidade Livre de Vincennes. Mas Deleuze dificilmente seria visto em barricadas, reuniões de comitês partidários e outras figurações do espírito de revolta presentes nos clichês da época. Para entender o que há de transgressor no pensamento de Deleuze é necessário ir além dessas territorialidades da contestação convencional e decodificada. A radicalidade de Deleuze se define pela mobilidade mercurial do ser nômade, de não se deixar inscrever nas 
malhas das palavras de ordem. Como no lema das rádios livres na década de 60: “piratas são eles - nós não, nós não queremos o poder”. É neste sentido que o pensamento de Deleuze é transgressor, por buscar incessantemente reunir elementos para uma ruptura absoluta. Uma ruptura por diferenciação e não por simples oposição binária.

Mas a palavra transgressão encontra-se debilitada por ter sido domesticada pelo marketing, pela moda e pela publicidade. Nestes domínios, transgredir é uma ação inscrita nas agendas e protocolos que a esvaziam por premeditarem e delimitarem seu alcance. A publicidade, o marketing e a moda transformaram a transgressão numa palavra de ordem. Uma transgressão absoluta é algo que não se anuncia, não se premedita. Uma transgressão é uma ruptura. Uma quebra. Uma ruptura é um acontecimento - ela não tem a priori. Isto impõe que algo ranja, que algo não funcione. Como isto é possível dentro de domínios regidos por princípios de eficiência e desempenho? Deleuze articula este pathos transgressor em seus escritos a partir do conceito de linha de fuga, que surge já no início da obra conjunta com Félix Guattari. Algo dele já está presente nas formulações inaugurais mesmas de O AntiÉtipo. As idéias de Maio de 68 estão ainda de alguma maneira fortes - o livro foi publicado pela Gallimard em 1972. Na base desse fenômeno de contestação cultural há uma influência muito forte do pensamento de Friederich Nietzsche, que ressurgia no cenario pós-guerra recuperado pelas leituras que o filósofo Alexander Kojéve propunha em seus seminários sobre Heidegger. Estes seminários influenciaram sobremaneira toda uma geração de pensadores: Deleuze, Guattari, Foucault, Derrida, entre outros. Deleuze havia publicado "Nietzsche e a Filosofia"45, livro que o coloca em evidência. Guattari vinha das experiências como psicanalista na Clínica de La Borde juntamente com

\footnotetext{
${ }^{45}$ DELEUZE, Gilles, Nietzsche e a filosofia. Rio de Janeiro, Editora Rio de Janeiro, 1976.
} 
Jean Oury e de seu trabalho no Grupo de Estudos Sobre as Prisões. Assim como Deleuze havia proposto em seu livro, a filosofia de Nietzsche trazia em si uma física, uma reflexão sobre o conceito de força e os desdobramentos deste em relação aos seus diferentes modos.

Não há como não pensar nas linhas de fuga quando Deleuze e Guattari exploram o conceito de rizoma, por exemplo. Isto quer dizer que, de forma latente, o conceito de linha de fuga já está entranhado no de rizoma. O que rizoma quer dizer em termos de conhecimento e filosofia, o conceito de linha de fuga o instaura em relação à política, isto é, no campo da ação. Para se traçar então a cartografia deste conceito filosoficamente político, é necessário entender em primeiro lugar o que é um rizoma.

A primeira vez que Deleuze e Guattari definem o conceito de rizoma acontece em $\mathrm{O}$ Anti-Édipo, recorrendo à imagem da relação entre a vespa e a orquídea. Ao atrair a vespa através do desenho de suas pétalas, a orquídea reproduz o desenho da uma barriga de uma vespa fêmea - isto ilude a vespa macho e acaba por incluí-la, agenciá-la diriam Deleuze e Guattari, em seu aparelho reprodutor. Por sua vez está na vespa o que permite à orquídea captura-la numa relação semiótica assimétrica. Uma captura de código entre a orquídea e a vespa. Esta imagem da qual se servem Deleuze e Guattari está presente no livro do colega de escola primária de Deleuze, Sexta-Feira (ou Os Limbos do Pacífico), do escritor Michel Tournier:

"Os seus devaneios tomaram um novo curso. Intrigava-o a
manobra de um himenóptero macho que só visitava uma
determinada espécie de orquídea, sem parecer interessado em
colher mel. Passou longas horas de lupa na mão, tentando decifrar
o comportamento do bicho. Descobriu primeiro que a flor
reproduzia exatamente, em matéria vegetal, o abdômen da fêmea
do inseto, a ponto de apresentar uma espécie de vagina, donde
provavelmente se desprendia um odor afrodisíaco específico,
próprio para atrair e seduzir o apaixonado. O inseto não pilhava a
flor; provocava-a, depois fazia amor com ela segundo os ritos da 
fecundação próprios da sua espécie. A Operação colocava-o numa boa postura para que o pólen, reunido em duas polínias, viesse fixar-se-lhe na fronte graças a duas pequenas cápsulas viscosas, $e$ era enfeitado com esse par de cornos vegetais que o ingênuo namorado prosseguia a sua colheita, de flor masculina para flor feminina, trabalhando pelo futuro da orquídea quando julgava servir a própria casta. ${ }^{, 6}$

Escolhemos essa passagem na obra de Tournier porque nela está evidenciada a transcodificação própria ao tipo de agenciamento que se produz num rizoma. A relação entre a vespa e a orquídea é transversal à estratificação 'flor feminina - flor masculina'. Ela faz o bloco inteiro 'fugir' em recíprocas desterritorializações de um elemento sobre o outro, de um código sobre o outro. Um rizoma portanto é uma transcodificação assimétrica entre dois regimes de signos heterogêneos que se torna independente, engajando seus termos formadores numa reciprocidade de devires. O devir orquídea da vespa, por exemplo, que é capturada numa codificação que a coloca como parte do órgão reprodutor da vespa e, por sua vez, o devir vespa da orquídea, que consegue atrair a vespa macho através de algo nela que a torna também algo de uma vespa.

Podemos ainda entender um rizoma segundo uma construção que coloca em contiguidade o pensamento de Gilles Deleuze e a música do grupo californiano Grateful Dead. Contigüidade que se desdobra para além da mera coincidência das iniciais de seus nomes: $G D+G D$. Tal como no título do diário filosófico-cinematográfico de Jean Luc Goddard: “JLG pour $J L G$ ”. É possível então pensar em algo como “Gilles Deleuze pour Grateful Dead”. É algo mais do que um jogo anagramático. O próprio Deleuze em sua última obra a quatro mãos com Félix Guattari ("O que é a Filosofia"47 ), explora uma

\footnotetext{
46 TOURNIER, Michel. Sexta-feira ou os Limbos do Pacífico. São Paulo, Clube do Livro, 1989. p.92.

${ }^{47}$ DELEUZE, Gilles e GUATTARI, Félix. O Que É a Filosofia. Rio de Janeiro, Editora 34, 1993.
} 
correspondência entre o plano dos afectos nas artes com o plano de imanência dos conceitos na filosofia. Ambos são formas de expressão do pensamento no campo das artes o pensamento se expressa através de blocos de sensações compostos por agregados sensíveis, intensidades - na filosofia o suporte sobre o qual o pensamento se expressa é o plano de imanência do conceito.

É possível então encontrar um correspondente estético na música do Grateful Dead enquanto agregado sensível o conceito de linha de fuga no pensamento de Deleuze segundo um conceito próprio da filosofia deste último: o rizoma. Esse correspondente diz respeito às "pontes" (bridges) improvisadas entre as músicas e que marcavam a passagem de uma canção para outra - marca característica da banda. Como afirmam Deleuze e Guattari:

"A cada vez que há transcodificação, podemos estar certos que não há uma simples soma, mas constituição de um novo plano como de uma mais-valia. Plano rítmico ou melódico, mais-valia de passagem ou de ponte - mas ambos os casos nunca são puros, eles se misturam na realidade (como a relação da folha não mais com a água em geral, mas com a chuva...). ${ }^{48}$

Em suas apresentações o Grateful Dead criava um fluxo contínuo de som que passava de uma música a outra através de intrincados bordados de uma teia de improvisações. Algumas apresentações da banda chegavam a extrapolar três horas de duração sem intervalos - uma jornada sensorial na qual cada música se colocava como um território cartografado de uma ilha dispersa na superfície pura e lisa de um oceano desterritorializante. Aqui há uma homologia formal entre filosofia e arte a partir do par conceitual espaço liso e espaço estriado, o qual se desenvolve em Mille Plateaux a partir de uma leitura deleuzoguattariana das teorizações do maestro e musicista contenporâneo Pierre Boulez.. O texto em questão está no volume 5 da edição brasileira do livro de Deleuze e Guattari: "O Liso e o Estriado". Como

${ }^{48}$ DELEUZE, Gilles e GUATTARI, Félix. Mil Platõs v.4. S ao Paulo, Editora 34, 1997. 
Deleuze e Guattari explicam, Boulez diferencia dois espaços que se apresentam através de uma música - um imediatamente reconhecido como constituído por "sons musicais", ou seja, produzido por instrumentos musicais dentro de um padrão de tempo, harmonia e timbre recon hecidamente musicais, ao qual ele chama de espaço estriado, e outro, constituído por sons que marcam uma pura diferença, sons que buscam um sentido musical, sons desterritorializados e que fazem o sentido musical deslizar para domínios mais amplos, ao qual ele chama de espaço liso. Essa diferenciação proposta por Boulez pode ser exemplificada com o tipo de música composta por Hermeto Pascoal, que tanto se constitui por "sons musicais" quanto pela inclusão de sons que eclodem como pura diferença construindo um sentido musical para além dos territórios demarcados do que se define como música. Essa tendência de incluir o "não-musical" ainda remete aos gestos musicais de John Cage, o uso da microfonia por Jimmy Hendrix ou ainda, no plano da teoria, ao musicista canadense Munrad Shaeffer. O espaço liso é o espaço que fundamenta a trangressão do sentido musical portanto. É o local da ruptura com o estabelecido enquanto musical. Logo, todo compositor se coloca na fronteira entre um espaço estriado, isto é, das normas e padrões instituídos como musicais, e um espaço liso, espaço não cartografado, um novo mundo possível ao qual se chega através de uma paisagem desconhecida. O espaço liso é a superfície pela qual correm as linhas de fuga. Não necessariamente contínuas e lineares, mas quebradas, erráticas como a muralha da china de Kafka, diz Deleuze.

A analogia com a música do Grateful Dead vem de uma imagem própria desse espaço liso que se forma num contexto musical. Em Skeleton Key os autores definem essa imagem no verbete THE ZONE: 
"The state of being to wich bandmenbers and the audience "travel" together when the music is at its most intense, exploratory, and collective.

Because Dead music is improvised music, the moment the gate to the zone swings open - when the "rusty strings" are dusted off and shine - always comes as a moment of surprise, of something made new. As Hart says, "Once in the zone, the point is to go somewhere you've never gone before".(...)

The zone is freedom - freedom to spin if you're a spinner, to stand with eyes closed wholly absorbed or flail madly throwing off sweat, to watch the levels on your tape deck dance during one of the great moments of your life." 49

O espaço liso estabelecido pelas linhas de fuga é o espaço de liberdade no qual habitam as singularidades. O conceito de linha de fuga é enunciado pela primeira vez em O Anti-Édipo e, já aí, está vinculado a algo de contracultural - os nome de Jack Kerouac.

“(...) O caso Kerouac, o artista dos meios mais sóbrios, o que fez uma 'fuga' revolucionária, e que se encontra em pleno sonho da grande América, e depois em busca de seus ancestrais bretões da raça superior. ${ }^{50}$ (p.252)

Essencialmente o conceito traz uma démarche deleuziana - o cuidado e inventividade no trato com a literatura. Depois Deleuze e Guattari seguirão adiante com o conceito em sua segunda obra conjunta: Kafka - Por Uma Literatura Menor, movimento que culminará com a nomadologia exposta em Mille Plateaux. Essencialmente uma linha de fuga é um investimento molecular no plano social. O conceito também está vinculado inicialmente ao conceito de grupo sujeito, o que requer uma explicitação à parte. A tendência

\footnotetext{
49 SILBERMAN, Steve e SHENK, David. Skeleton Key - A Dictionary for Deadheads. New York, Main Street Bookes - Doubleday, 1994. pp. 336-337 Numa tradução livre:

"Estado de ser no qual os membros da banda e a audiência viajam juntos quando a música está em seu ápice de intensidade, experimentalismo e coletiva.. / Porque a música do Dead é música improvisada, os portões para a Zona estão a todo momento livres e abertos quando as "cordas empoeiradas" são espanadas e brilham - sempre acontece como um momento de surpresa, de algo feito novo. Como Mickey Hart (bateirista da banda) diz, "Uma vez na Zona, a questão é ir aonde você nunca foi antes.."(...)

A Zona é liberdade - liberdade de rodopiar se você rodopia, de ficar com os olhos fechados completamente absorto ou sacudir loucamente espalhando suor, olhar os leds do seu aparelho de som dançarem durante um grande momento da sua vida".

50 Anti-Édipo p.252.
} 
é, numa leitura mais aligeirada, atribuir a Deleuze e Guattari a voz oficiosa do individualismo yuppie da década de 80 - risco apontado por Slavoj Zizek em seu livro "Organs Without Bodies" ${ }^{51}$. Isto se dissipa com um olhar mais cauteloso sobre o texto barroco dos dois autores. Quando se fala no par molar/molecular, Deleuze e Guattari têm em mente o que isto significa em termos próprios da física. Estruturas molares obedecem a leis estatísticas próprias de um entorno dado pela macrofísica, enquanto estruturas moleculares são próprias de fenômenos da microfísica, ou seja, de relações que escapam as grandes generalizações - em outros termos, das singularidades. Há aqui uma tendência a transferir sem nenhum rebatimento a noção para um contexto sócio-político assimilando coletivo a molar e individual a molecular. É aí que Deleuze e Guattari executam um salto conceitual -

\begin{abstract}
"Dir-se-ia que das duas direções da física, a direção molar que se orienta para os grandes números e os fenômenos de multidão, e a direção molecular que se aprofunda, pelo contrário, nas singularidades, suas interações e suas ligações à distância ou de ordens diferentes - o paranóico escolheu a primeira: ele faz macrofísica. E que o esquizo, ao contrário, vai na outra direção, a da microfísica, das moléculas enquanto elas não obedecem mais às leis estatísticas; ondas e corpúsculos, fluxos e objetos parciais que não são mais tributários dos grandes números, linhas de fuga infinitesimais, em lugar das perspectivas de grandes conjuntos. E, sem dúvida, seria um erro opor essas duas dimensões como o coletivo e o individual." 52
\end{abstract}

Decorre dessa diferenciação entre molar e molecular o fato de Deleuze e Guattari entenderem como singularidade o resultado da ação de uma linha de fuga. O que faz alguma coisa escapar aos domínios estatísticos de um grande conjunto, portanto, é o que se produz a partir de um movimento enquanto

\footnotetext{
${ }^{51}$ ZIZEK, Slavoj. Organs Without Bodies: Deleuze and consequences. New York/ London, Routledge, 2003.

${ }^{52}$ DELEUZE, Gilles e GUATTARI, Félix. O Anti-Édipo. Rio de Janeiro, Imago, 1976. p.355
} 
singularidade. Não necessariamente individual. Uma singularidade coletiva é o que fundamenta um grupo sujeito. Pensar então em uma política em termos deleuzoguattarianos é colocar-se em convergência com movimentos que levam à formação de singularidades. Não há como deixar aqui de aproximar essa noção de singularidade com a de diferença. Uma linha de fuga é um movimento de diferenciação pelo qual o singular se afirma. O inclassificável segundo as axiologias vigentes. Garrincha é uma linha de fuga. Mas também Jimmi Hendrix, o Impressionismo, os Provos da Holanda, a música de Hermeto Pascoal e todos os outros nomes de pessoas, de grupos, de fenômenos que não se deixam esmagar pelo peso do comum, do mediano, do estabelecido e comprovado e legitimado por maiorias estatísticas. Nesse sentido toda linha de fuga é um movimento menor, em direção do menor, do molecular em sua essência. A linha de fuga é o princípio pelo qual se elabora o incomum. Nada é mais avesso à comunicação de massa, portanto, do que uma linha de fuga.

Temos então que por princípio toda comunicação de massa é dada por uma orientação molar. É possível então entender a aversão de Deleuze pela mídia em geral - o que ele expressa em outra obra escrita a quatro mãos com a jornalista Claire Parnet: Diálogos. Parnet foi quem realizou o longo conjunto de entrevistas que foram divulgadas somente depois da morte de Deleuze, o Abecedário Deleuziano. Tanto no livro com Parnet, quanto na série de entrevistas, Deleuze expõe, num raro momento em que considera o problema da comunicação de massa na contemporaneidade, sua maneira peculiar de entender o que se passa nesse campo. 
Bach Pynchon e Deleuze - Três gênios aqui entrelaçados como uma variação da inflexão feita por Douglas Hofstadter ${ }^{53}$ para entender o fenômeno das voltas estranhas. Há momentos especiais em alguns sistemas hierárquicos em que uma certa abertura se pronuncia na forma pela qual se introduz uma diferença tal qual como na invenção das fugas de Johan Sebastian Bach, de forma a mudar o tom imperceptivelmente. O tema de uma fuga se repete ao construir suas diferenciações. Ao se repetir seis vezes o procedimento de variar o tema segundo o tom eis que se volta ao tema original do qual se partiu. A leitura de Hofstadter do engenho musical de Bach encontra eco no pensamento filosófico de Gilles Deleuze, o qual se pauta por uma filosofia da diferença; de inspiração nietzschiana, Deleuze concebe toda e qualquer diferença como fundamentada na repetição. Uma leitura singular do tema do eterno retorno em Nietzsche: se nada volta no tempo, então a impossibilidade da volta sempre retorna. Não há oposição entre diferença e repetição, mas a complementaridade de um ciclo vicioso.

Mas não é só neste contexto que os gênios de Deleuze e Bach se entrelaçam. Para além da diferença e repetição o próprio tema da fuga em si lhes é comum. Para Deleuze nada é mais importante do que as fugas. Não no sentido de um abandono passivo em relação aos constrangimentos da história, da política ou da cultura. Uma fuga jamais se constitui em escapismo, mas numa ação afirmativa em relação às potências da vida como diferença. Toda fuga é ativa no sentido em que a partir dela se traça uma linha pela qual algo escapa das codificações instituídas. Uma linha de fuga. É possível percebe-la insinuando-se a partir dos agenciamentos, das configurações que produzem um dado momento histórico, cultural, político. Uma linha de fuga é uma

\footnotetext{
${ }^{53}$ HOFSTADTER, Douglas R. Gödel, Escher e Bach - Um Entrelaçamento de Gênios Brilhantes. Brasília, Imprensa Oficial - UNB, 2001.
} 
desterritorialização. Um apagamento das definições que seguem a linha de algum contorno delimitado em um gênero, uma instituição, enfim, um território cartografado.

A fuga em si é o que para Deleuze leva ao intensivo - categoria nem sempre acolhida pelo pensamento ocidental. Não o corpo biológico, mas o corpo erógeno. O corpo sem órgãos do qual fala Artaud. Pura intensidade. Pathos. A paixão. O dionisíaco, a embriagues e a vertigem:

Uma fuga é uma espécie de delírio. Delirar é exatamente sair dos eixos (como "pirar" etc). Há algo de demoníaco, ou de demônico, em uma linha de fuga. ${ }^{54}$

Todos esses sentidos do intensivo estão presentes no fenômeno histórico da contracultura. Principalmente em termos da ação política decorrente dos valores que pautaram este movimento. Segundo Theodore Roszak, o que define a contracultura é um determinado tipo de ação política espontânea que busca fugir ao enquadramento disposto pelas territorialidades da política convencional entre uma orientação de esquerda e outra de direita. Nem uma nem outra. A contracultura foi uma síntese disjuntiva cravada no coração tecnocrático do mundo pós-guerra. As práticas políticas no contexto da contracultura desenvolveram-se segundo um pressuposto de que, ao se auto-incluir a militância como oposição à direita já é aceitar um enquadramento - aceitar as regras pelas quais o campo da política se estabiliza em um determinado tipo de poder que depende desta aceitação, portanto já é reproduzir o poder que enquadra como "de esquerda" o que pode significar uma decodificação política. A emergência da pura diferença. Uma fuga em termos deleuzianos. E é Deleuze quem diz que se deve ler Nietzsche como o lêem os jovens da contracultura - dando gargalhadas. O pathos, a intensidade

\footnotetext{
${ }^{54}$ DELEUZE, PARNET. Op.cit. p53
} 
como nas paixões alegres de Espinosa. Descentramentos que expandem o ser porque ele se reconhece nesse movimento de deriva de si num sempre outro. Alegria da poesia de Rimbaud, padroeiro de todos os drop outs: "é que eu é um outro!"

É na obra de Thomas Pynchon, um dos principais retratos da contracultura, que se define uma forma de desejo contracultural como linha de fuga. Esta é a perspectiva é do crítico americano Stephen Mattesich ${ }^{55}$. Em sua leitura, Mattesich detecta que, ao longo de toda sua obra, Pynchon cria um universo todo de referências espatifadas ao espírito do tempo da contracultura. Segundo Mattesich este universo se define pela intensidade que atravessa seus personagens quando estes se colocam em fuga. O desejo contracultural, reconectar-se com a linha quebrada que resgata o trancendentalismo de Henri David Thoreau, é vivido por toda personagem que revela tensões no sentido de voltar à natureza como força primitiva e original. Esse traço da cultura de contestação das décadas de 50-60 nos EUA é captado por Pynchon tanto em Cry of Lot 49, quanto em Vineland e Rainbow's Gravity. É comum a estas obras o desejo que se manifesta em algum personagem que resolve desertar da convocação para a luta no Vietnã fugindo para o Canadá. Esta fuga para o norte é o que traça uma linha de fuga na obra, posto que ao se colocarem a caminho a narrativa se coloca sobre uma linha de fuga que carrega consigo toda a linguagem que se desestabiliza de seus condicionamentos sociais numa busca por um rompimento com a palavra de ordem.

\footnotetext{
55 MATTESSICH, Stefan. Lines of Flight - Discoursive Time and Countercultural Desire in the Work of Thomas Pynchon. Londres e Durhan, Duke University Press, 2002.
} 


\section{New Journalism -um modelo contracultural}

Assim como Mayra Rodrigues Gomes nos mostra em seu livro sobre filosofia da comunicação, o jornalismo também pode ser entendido como dispositivo disciplinar. Isto é, o jornalismo é uma prática discursiva que dispõe aquilo que se pode apreender em um determinado momento histórico. Sob uma aparente abertura, os dispositivos enquadram o campo da experiência segundo coordenadas muito precisas. Os dispositivos disciplinares são operadores discursivos pelos quais se comunicam comandos. Sua lógica é constituída de oposições binárias que aparentemente são abertas mas que na verdade impõem um rebatimento rigoroso da percepção e experiência sobre estratificações como homem, mulher, criança, adulto, esquerda, direita e assim por diante. Um dispositivo disciplina todo um campo de possíveis que se pronuncia entre estas estratificações que polarizam a experiência. Existe toda uma gradação possível que é rebatida sobre o peso das estratificações. Ou um extremo ou outro. A este efeito que sobrevém dos dispositivos disciplinares, Deleuze e Guattari chamam de palavra de ordem, um conceito que aparece em sua obra conjunta Mille Plateaux. A palavra de ordem é o comando que inconscientemente se reproduz através da ação dos dispositivos disciplinares. Um dispositivo então territorializa um campo de possibilidades sobre estratificações fixas. Se o jornalismo então pode ser entendido como dispositivo disciplinar, também podemos pensar que é um meio de reprodução de palavras de ordem. O jornalismo impõe um quadriculamento da realidade ao aplicar sobre a realidade da experiência um gabarito, uma axiologia. Isto o destitui da pretensa objetividade e isenção que as empresas de comunicação apregoam e que os cursos de jornalismo em sua maioria reproduzem acriticamente. Uma palavra de ordem é uma marcação de poder. O jornalismo 
convencional constituindo-se como dispositivo disciplinar é uma instância pela qual os poderes vigentes se reproduzem. Por onde então pensar novamente os possíveis e liberá-los das palavras de ordem. Grande parte da obra conjunta de Deleuze e Guattari se dedica a pensar exatamente a questão das multiplicidades, da diferença. Da gama de possíveis que se estende de um extremo ao outro:

A esquizo-análise deve aqui desembaraçar o fio. Porque ler um texto não é nunca um exercício erudito em busca dos significados, menos ainda um exercício altamente textual em busca de um significante, mas um uso produtivo da máquina literária, uma montagem de máquinas desejantes, exercício esquizóide que retira do texto sua potência revolucionária. ${ }^{56}$

Esquizo-análise como contraposição a psicanálise - o esquizo como abertura para o imediatamente histórico contra o fechamento da psicanálise sobre o segredo familiar e a confissão sobre o divã. O tipo de investigação que Deleuze-Guattari propõem é então o rastreamento dessas conexões a fim de observar como determinado agenciamento é constituído em suas relações internas, a formação de suas máquinas, e de como este mantém conexões com outros agenciamentos que lhe são adjacentes ${ }^{57}$. Deleuze-Guattari chamam a este procedimento de Esquizoanálise, para marcar a diferença de seu método em relação à psicanálise. Esta última busca sempre um centro que sirva de elemento de identidade num processo. Na esquizofrenia, o que se rompe é exatamente esta estrutura básica da psicanálise; o ego é fragmentado. A força que espalha os estilhaços dessa estrutura é uma força centrífuga, de expansão em todos os sentidos, como na proliferação desencadeada por um rizoma.

\footnotetext{
${ }^{56}$ DELEUZE, Gilles e GUATTARI, Felix. O anti-Édipo. Rio de Janeiro, Imago, 1976. p139.

${ }^{57}$ DELEUZE-GUATTARI. Anti-Édipo cap.01.
} 
A esquizoanálise seria então uma prática de mapeamento dessa força centrífuga. Seu protocolo é seguir o que escapa ao centro de recognição e de identidade. Traçar um mapa do desconhecimento de si que o jornalismo experimenta ao se mestiçar de literatura. $\mathrm{O}$ texto jornalístico que se propõe contrapor as potências fixas que o recortam como dispositivo disciplinar assume um devir literário e passa para uma outra modalidade. Como na experiência do New Journalism, nem jornalismo, nem literatura, mas ambos ao mesmo tempo nas duas direções. Rizoma entre jornalismo e literatura. Assumindo uma linha que desmancha as formas estáticas produzidas pela parada do processo de sua produção. Linha que nasce desse encontro e que arrasta os dois domínios para um plano em aberto, como num deserto. O crítico Boris Schnaiderman define esta relação da seguinte maneira:"em termos modernos, a literatura e o jornalismo são vasos comunicantes, são formas diferentes de um mesmo processo" ${ }^{58}$. Disto se deduz que são polos complementares, que se colocam nos extremos da linguagem, e que, como tal, tocam-se na circularidade das relações que estabelecem entre si. O fim de uma forma de escrita é o princípio da outra.

Entre a contracultura como expressão social e histórica e o new journalism como fenômeno estético literário existem bem mais coisas em comum do que apenas uma coincidência cronológica. A contracultura nasce do desencanto em relação ao american way of life a partir do pós-guerra nos EUA. O new journalism é um fenômeno que, por um lado, diz respeito à emergência da chamada imprensa underground nos EUA na década de 60 e, por outro, a uma forma de enxerto e hibridização de jornalismo e literatura forjada por autores como Tom Wolfe, Gay Talese, Norman Mailer, Hunter Thompson, entre outros. Ambos os fenômenos, dentro dos entornos que lhes

\footnotetext{
${ }^{58}$ in LIMA, Edvaldo Pereira. Ibdem. p.139.
} 
são peculiares, construirão nas leituras que os recuperam a partir da história como grandes momentos, seja de um reencantamento da experiência do mundo, seja de uma forma de escritura singular que se propôs a narrar esse momento.

Enquanto conceito, contracultura designa uma série de sentidos que se desdobra em torno da idéia de uma resistência aos padrões socialmente estabelecidos. O termo eclode no discurso teórico a partir da obra do sociólogo americano Theodore Roszak, quando este avaliava um perfil geral dos movimentos de contestação nos anos 60 contra a guerra do Vietnã, a favor dos direitos civis dos negros, a nova boemia urbana da beat generation, os hippies, o Haight Ashburry, o Partido Internacional da Juventude (Yippie!), enfim as características que indicavam uma certa identidade, um espírito do tempo que ganhava as ruas naquele momento histórico.

Em quase toda a sua totalidade a contracultura foi absorvida de maneira lenta e letal porque assimilada como excentricidade. Do espírito utópico moderno que a animava passa a emanar o solvente ideológico que a resgata como motriz de uma versão especializada da indústria cultural: a indústria da revolta.Não existe uma definição que dê conta de algum tipo de jornalismo que tenha sido contracultural em essência a não ser a de Michael Johnson, em seu livro "The New Journalism - Understanding Press, the Artists of NonFictiom, and Changes in the Estabilished Media" de 1971, relaciona o Novo Jornalismo à contracultura.

Este capítulo busca explorar exatamente as possibilidades que a aproximação desta escola americana de jornalismo com o fenômeno da contracultura sugerem como pressupostos para uma prática jornalística alternativa em relação aos padrões ditados pelo mercado de comunicação 
contemporâneo, bem como mapear as principais influências na prática jornalística de contestação aos modelos adotados pela grande imprensa.

No caso específico do New Journalism, esta contestação se dá pelo investimento na experimentação estética do discurso jornalístico - essa é a característica fundamental deste fenômeno - o que o coloca em choque frontal com os valores sobre os quais se assenta a concepção característica da linguagem jornalística. $\mathrm{O}$ assunto rende um tom preponderantemente polêmico por se instalar numa zona de conflito dada pela ética. O que está em jogo é a territorialidade demarcada por valores sedimentados ao longo b processo histórico que estratifica o jornalismo na lógica da "capitalização do espírito" apontada por Lukacs em sua leitura de "Ilusões Perdidas", de Balzac. Seguindo esse autor, José Miguel Wisnik descreve a paisagem desse conflito dramatizado pela obra de Balzac:

"Os poderes do jornalismo são objeto de uma anatomia virulenta:
para Balzac a imprensa parece concentrar o mal do mundo
consumado na mercantilização, dissipando o lastro do valor
universal e pulverizando todo compromisso ético. (...) o que está
em questão nessa poderosa obra de arte é o destino problemático
da própria literatura diante dessa nova máquina de representar o
mundo: o jornal diário e de massa.(...) A expansão da indústria
editorial cria o campo litigioso em que se confrontam, no mesmo
veículo, através da representação literária e da representação
jornalística, duas formas de ficção que disputam a mimese da vida
moderna

Essa estratificação do jornalismo num contexto que o vincula à expansão do mercado editorial desde o século 19 o coloca em litígio em relação à literatura. Há um conflito instalado na demarcação de um novo modo de semiotização que é genético em relação ao jornalismo como modalidade discursiva. Balzac o vê como detentor de um valor

\footnotetext{
${ }^{59}$ WISNIK, José Miguel. As Ilusões Perdidas de Balzac. In NOVAES, Adauto. Ética. São Paulo, Cia das Letras, 1992 pp.323-324.
} 
fundamentalmente decadente onde o que prevalece é a licenciosidade dos "espadachins das frases feitas". É que a emergência dessa nova maneira de representar o mundo arroga para si a legitimidade que na literatura foi conquistada pelo realismo, onde a referencialidade e a perspectiva são fundantes de sua estética singular.

O realismo demarca um território fundamental para a literatura no modernismo: a emergência de uma estética em que a linguagem é vista como uma matéria a ser moldada através da experimentação na prosa. Em nenhum momento o realismo aqui significa uma concepção da linguagem atrelada ao conteúdo, mas o refino de sua potência expressiva na representação de sua própria condição de discurso. Em termos psicanalíticos, o realismo se define pelo "real que falta" - lei que se revela na linguagem como apreensão desta falta. No realismo não se constroem representações fundamentadas num suposto valor de uma linguagem equivalente à realidade, mas a realidade da linguagem propriamente dita. Paulo Leminski é quem avalia o conflito apontado por Wisnik nas "Ilusões Perdidas", confrontando o realismo com o naturalismo na literatura em relação à forma de legitimação discursiva reivindicada pelo jornalismo:

\begin{abstract}
"Invoca-se em vão o nome do realismo, que se procura confundir com o naturalismo. Realismo, quer dizer, discurso carregado de referencialidade, não é sinônimo de naturalismo. Ao contrário. $O$ discurso realista não camufla a perspectiva. Realistas (e não naturalistas) são textos como o 'Ulysses', de James Joyce. Ou as 'Memórias Sentimentais de João Miramar', de Oswald de Andrade ${ }^{\prime 60}$
\end{abstract}

Para Leminski, o valor sobre o qual o jornalismo busca legitimar sua forma discursiva é uma assimilação do naturalismo. Neste, ao contrário do

\footnotetext{
${ }^{60}$ LEMINSKI, Paulo. Forma é Poder. Folha de São Paulo, Folhetim 04/07/1982.
} 
realismo, é o conteúdo e não a forma, que é visto como determinante no plano da linguagem. $\mathrm{O}$ naturalismo pode aqui ser entendido como uma estética na qual a linguagem é vista como uma positividade.

A partir do que propõe Leminski pode-se entender a relação entre a concepção de linguagem do realismo em confronto com o discurso jornalístico como uma extensão das diferenças que este entretém com o naturalismo:

"Naturalismo, academicismo. O apogeu do naturalismo (Europa, segunda metade do século 19) coincide com a explosão do jornalismo. $O$ discurso jorno/naturalista representa o triunfo da razão branca e burguesa: o discurso naturalista é a projeção do jornalismo na literatura". ${ }^{61}$

Note-se que o período apontado por Leminski coincide exatamente, no plano histórico, com o conflito detectado por Lukacs na obra de Balzac. Seguindo a linha traçada por Leminski, o jornalismo pode ser entendido como uma forma de discurso na qual se projeta a concepção de linguagem cara ao naturalismo:

"A 'neutralidade' (objetividade) do discurso jorno/naturalista é uma convenção. Assim como a clareza, apenas uma propriedade (retórica) do discurso. Não há texto literário sem perspectiva, quer dizer, sem intervenção da subjetividade. No texto naturalista (ou jornalístico), essa perspectiva é camuflada, sob as aparências de uma objetividade, uma Universalidade que - supostamente - retrata as coisas 'tal como elas são'"'62

Daí a origem dos protocolos que irão sedimentar uma discursividade construída sobre a transparência calculada do conteudismo jornalístico. A imagem de uma objetividade que é reflexo da ideologia que a sustenta:

\footnotetext{
${ }^{61}$ LEMINSKI. Ibdem.

${ }^{62}$ Idem
} 
"No discurso jorno/naturalista, o poder afirma, sob as espécies da linguagem verbal, a estabilidade do mundo, de um certo mundo, suas relações e hierarquias. $O$ discurso, esse, em sua aparente neutralidade, é ideológico, embora invisível (ou por isso mesmo): é ideologia pura. Sua estabilidade é catártica: nos consola e engana com a imagem de uma estabilidade do mundo. De um certa estabilidade. Uma estabilidade relativa à visão do mundo de uma dada classe social muito bem localizada no tempo e no espaço". ${ }^{63}$

É esta a estratificação que fundamenta o jornalismo no plano da linguagem. Seu ethos é decorrente de uma normatização segundo os valores que emergem do poder que se insinua no apetite das manchetes ávidas muito mais pelo efeito que podem provocar nas vendas do que representar algo de um mundo. Para Leminski, existe um devir poético na recuperação de uma potência realista da linguagem no jornalismo. Tal potência é exatamente a mesma que fundamenta o fenômeno do New Journalism.

Segundo Tom Wolfe, o que caracteriza o New Journalism é uma atitude crítica em relação aos modelos do que ele chama de "jornalismo totem" ${ }^{64}$. Crítica que encontra sua expressão no experimento estético, carregando o texto jornalístico de referencialidade num movimento oposto a um investimento no conteúdo. A forma do discurso é tratada como artifício e, em nenhum momento se constrói nada que encubra este estatuto. Isto faz com que a discursividade do New Journalism seja uma desconstrução exemplar da objetividade jornalística. Isto pode ser exemplificado pelo recurso literário do fluxo de consciência que Wolfe insere em seu livro-reportagem "The Eletric Kool-Aid Acid Test" (1968), sobre os Merry Pranksters (grupo que na década de sessenta acompanhava o escritor Ken Kesey).

\footnotetext{
${ }^{63}$ LEMINSKI. Ibdem.

${ }^{64}$ WOLFE, Tom. The New Journalism. New York. Harper \& Row, 1973
} 
Wolfe trabalhou com materiais espúrios ao jornalismo convencional, consultando cartas em que Kesey descrevia a amigos suas experiências com drogas e seus sonhos, como base para criar estes fluxos de consciência. À objetividade, tabu do jornalismo, se contrapõe aqui um investimento na subjetividade. Segundo Leminski, no mesmo artigo da "Folha" acima citado, tal recurso é legítimo no sentido de se recuperar a potência realista projetada então para o discurso jornalístico:

\begin{abstract}
"Uma prática do texto criativo, coletivamente engajada, tem a função de desautomatizar. De produzir estranhamento. Distanciamento. É desmistificação de 'objetividade' inscrita no discurso naturalista. Essa objetividade é falsa. Ela apenas reflete a visão do mundo de dada classe social, de determinada civilização. Sua pretensão a 'discurso absoluto' é totalitária. Violação. Ruptura. Contravenção. Infratura. A poesia diz 'eu acuso'. E denuncia a estrutura. A estrutura do Poder, emblematizada na 'normalidade' da linguagem. Só a obra aberta (desautomatizada, inovadora), engajando, ativamente, a consciência do leitor, no processo de descoberta/criação de sentidos e significados, abrindo-se para sua inteligência, recebendo-a como parceira e co-laboradora, é verdadeiramente democrática".
\end{abstract}

É diante de um plano assim que se pode tomar o New Journalism como uma forma de jornalismo contracultural. Não somente pela conformação dada pelo âmbito histórico no qual ele se inscreve enquanto fenômeno, mas principalmente por investir num conflito que a normatização do discurso jornalístico buscou suprimir através de um discurso de poder que assujeita o leitor numa passividade característica da indústria da cultura. Por contracultural entenda-se aqui o quadro definido por Norbert Elias e John Scotson em "Os Estabelecidos e os Outsiders" (2000). O fato de haver um "establishment" do jornalismo pressupõe a existência de um plano de exclusão que o fundamenta. Não há poder estabelecido sem o recorte que este produz. 
Todo poder se nutre das relações pelas quais o "establishment" se afirma sobre o que se coloca fora de suas determinações.

Um jornalismo contracultural seria toda a forma de investimento em valores clandestinos à estratificação do jornalismo convencional. Contracultural, neste contexto, portanto, é toda forma de jornalismo que se alinha ao conflito que se torna visível sobre o plano no qual o New Journalism se instala. Conflito ético porque inscrito no valor fundamental da estratificação do jornalismo: a verdade. Como discute Leminski, a verdade do discurso jornalístico tradicional suprime uma verdade anterior - a da linguagem enquanto artifício. Dessa maneira, o jornalismo não escapa de uma reiteração dos valores que sustentam um poder que conforma a sociedade segundo um modo de semiotização dominante. $\mathrm{O}$ apelo a um estatuto democrático então não passa de uma construção ideológica. Um jogo de poder pelo qual o assujeitamento do leitor em sua passividade é sintoma de uma ordem política que o territorializa assim.

A objetividade jornalística pode ser entendida então como um dispositivo de controle no sentido que Michel Foucault dá ao termo. Quanto mais se apela ao fundamento democrático do jornalismo, se constrói ao mesmo tempo uma ordem rígida na qual os leitores são capturados num jogo de poder. O jornal pode ser entendido como uma rede, um quadriculado que confina, imobiliza e controla. Mas esta é a paisagem que se vê do ângulo do que é estabelecido na mídia. Existe uma virtualidade de outras perspectivas pelo menos enquanto possibilidades. Uma abordagem arqueológica nos moldes propostos por Foucault sugere possibilidades de exploração das sombras que o discurso estabelecido do jornalismo lança sobre os seus segredos de poder. A vocação contracultural do New Journalism talvez seja 
uma das mais evidentes por problematizar o jornalismo enquanto fato lingüístico, o que não é uma abordagem comumente partilhada pela produção acadêmica na área - problema apontado pela professora Mayra Rodrigues Gomes em seu "Jornalismo e Ciências da Linguagem" (2000).

O fenômeno do New Journalism e de alternativas afins, como o que nos países de língua espanhola se chama de "periodismo informativo de creación"65 têm uma abordagem relativamente recente nos estudos sobre jornalismo no Brasil. Textos de Edvaldo Pereira Lima, Fernando Resende, José Salvador Faro e Marcos Faerman abrem essa discussão que problematiza o jornalismo a partir da sua interseção com outras formas de construção de relatos e narrativas como a literatura e a história. Tal perspectiva tem como horizonte a discussão das possibilidades de ampliação dos recursos pelos quais o jornalismo se constitui como prática discursiva. De maneira convergente, estes autores partem do New Journalism como uma referência pela qual se pode projetar uma ruptura com o modelo de texto noticioso que invadiu as redações dos periódicos brasileiros a partir da década de quarenta.

Aparentemente, a primeira vez no Brasil que o termo jornalismo emerge diretamente relacionado ao fenômeno histórico que Theodor Roszak batizou de contracultura foi no subtítulo do livro de Luís Carlos Maciel - "Nova Consciência - Jornalismo Contracultural" -, publicado pela Editora Eldorado em 1973. Maciel havia organizado em forma de coletânea uma amostragem da sua produção jornalística na coluna Underground do "Pasquim" e nas páginas marginais da "Flor do Mal" - nanico que ajudou a fundar em 1970 juntamente

\footnotetext{
${ }^{65}$ Existe um fenômeno similar em relação à imprensa australiana da década de 80 conhecido como Ferret Journalism ("jornalismo furão")
} 
com o poeta Torquato Mendonça, Tite Lemos e o artista gráfico e também poeta Rogério Duarte.

A capa do número zero da "Flor do Mal" trazia a foto de uma menina negra que o também jornalista, poeta e compositor Torquato Neto havia achado desprezada no chão da redação do "Última Hora", jornal para o qual trabalhava na época, então publicando a sua coluna Geléia Geral. Talvez esta capa seja o ícone dessa nova dicção no jornalismo brasileiro. Isto porque reúne sob uma mesma imagem os nomes de Maciel e Torquato Neto. Dois nomes pelos quais é obrigatória a passagem para se ter acesso à forma de cultura de resistência que se desenvolveu no período mais duro da repressão militar no país.

Torquato Neto desenvolveu um estilo radicalmente singular de texto jornalístico que não encontra par em coragem de experimentação estética e inventividade. Maciel marcou o início de sua produção no "Pasquim" com a coluna pela qual se articulou uma pedagogia contracultural da cena "underground". (Atribui-se a Glauber Rocha a origem do termo "udigrudi", que, a partir da década de setenta, passou a designar a cena da cultura marginal que não se relacionava imediatamente com as formas convencionais de resistência política à ditadura militar - o cinema marginal de Sganzerla, Bressane, por exemplo. Glauber usava "udigrudi" certamente pelo seu desafeto em função da ruptura do cinema marginal com o cinema novo.)

Maciel abordava desde o Living Theatre, Abby Hoffmann até a antipsiquiatria de Laing e Basaglia. Ambos podem ser apontados como os detonadores de uma forma de discurso jornalístico enlouquecida, fragmentária, poética: contracultural. Um jornalismo que além de nanico era 
também marginal - acima de tudo marginal. Fusão do desbunde ao programa libertário da contracultura curto-circuitada à própria forma do discurso jornalístico.

Frente a um mercado de comunicação que coloca sérios impasses à prática do jornalismo impresso - impasses que devem ser problematizados desde o advento da introdução das novas tecnologias de comunicação até a reconfiguração de horizontes projetada por contextos históricos, culturais e políticos como a pós-modernidade e a globalização - é necessária a discussão de um novo perfil que possa libertar o jornalismo impresso do mito da informação pura; dimensão pela qual ele se torna obsoleto diante do que permitem as novas tecnologias.

Retomando a própria origem deste "modelo americano" que é a expressão do discurso jornalístico estabelecido, há uma relação direta da forma do lead, por exemplo, com o que gerou a imagem e o conceito de rede de comunicação segundo Mattelart: o telégrafo. Essa tecnologia foi a concretização, num aparelho, dos ideais do imperialismo que caracterizou o plano da política internacional que define século 19. A partir do cabeamento sob o Atlântico se tornou possível a cobertura de acontecimentos na Europa por parte de periódicos americanos.

Como as linhas eram ainda precárias e em algumas situações o risco de queda da rede era muito grande, como numa guerra, convencionou-se que a abertura de uma matéria deveria conter os dados fundamentais sobre o acontecimento - convenção que gerou o que hoje se chama de lead (cabeça de matéria). Esse procedimento garantia que mesmo com uma queda e a interrupção da mensagem transmitida pelo correspondente haveria a 
possibilidade de, a partir dos dados básicos do lead, reconstruir a notícia. É uma lógica baseada no conceito de informação.

O desenvolvimento da web segue o mesmo princípio. Arede opera em "tempo real" num espaço virtual marcado pela aceleração. Neste contexto, a informação reina soberana mais uma vez e, como tal, ela impõe sua força pelo próprio modelo de processo da comunicação que a gerou, concepção essa assumidamente tecnicista. Isto faz com que a urgência do jornalismo, sob o julgo de uma linguagem depurada de qualquer entropia, possa ser atualizada pela rede em tempo real. Não é mais a precariedade, mas o seu oposto, a radicalidade da eficiência técnica que gera uma nova roupagem do conceito de informação a partir das novas tecnologias.

O modelo vingou em função da sua natureza pragmática, mas o problema é que ele se estagnou num dogma que não encontra mais a legitimidade que a precariedade técnica lhe garantia. A informação mudou de estatuto e, segundo o próprio plano teórico sobre o qual foi gerado este conceito, a questão que se coloca não é mais a de uma codificação eficiente que pudesse maximizar a utilização de um canal. $\mathrm{O}$ meio físico pelo qual se propagavam as mensagens telegráficas deu lugar a uma realidade em que impera uma complexidade de suportes pelos quais se cria uma rede mundial de computadores interconectados.

O virtual é a nova dimensão da informação e, enquanto tal, sua dispersão descentrada impõe uma nova lógica. A maneira pela qual se emprega o conceito de informação no jornalismo ainda é marcada pelo tipo de informação que se atualizava num suporte concreto (canal) em sua transmissão. Seguindo o diagrama de Deleuze e Parnet sobre as práticas de 
comunicação temos que este modelo ainda definido pela Era Mecânica (McLuan), a redundância se coloca como elemento fundamental.

A informação dentro do quadro de relações que a técnica possibilita a partir da web é virtual, desterritorializada sobre uma complexa rede e não mais localizada sobre um canal específico. A convergência de mídias pode ser entendida como uma desterritorialização dessa ordem. Isto evidencia a possibilidade de um investimento sobre a dimensão agramatical e desterritorializante das linhas de fuga tal como Deleuze e Parnet apresentam em sua lógica de inversão da informação, que passa a ser entendida como o mínimo necessário para que haja legibilidade no processo de comunicação.

É inegável que na construção da notícia o modelo tradicional do lead seja uma forma de codificação eficiente. A lógica da informação que serviu de base para a geração de seu modelo não se encontra mais nas mesmas condições de sua gênese. As linhas de fuga da Era Eletrônica, tal como McLuhan definiu, são é descentradas e relativamente independentes de um meio físico. É diante de um cenário assim que o resgate da marginalidade do discurso jornalístico que se encontra na origem de sua estratificação representa um horizonte pelo qual se insinuam possibilidades de uma discussão de ordem ética.

Um jornalismo que conteste a si mesmo como condição para uma nova ética que lhe dê um sentido crítico ao invés dos discursos pretensamente democráticos, mas que reconstroem a cada signo uma situação de poder com a qual nunca conseguem romper. Um jornalismo contracultural que retome a linha de fuga traçada pelas experiências do New Journalism e da marginália de Torquato Neto; o underground de Luiz Carlos Maciel. Um jornalismo de 
"transvaloração de todos os seu valores", no sentido nietzschiano e, de "descentramento de todos os sentidos" tal qual na poética de Rimbaud.

Somente assim é possível vislumbrar uma ruptura com a palavra de ordem que reside no termo democracia entendido como falso valor a partir de uma automatização do discurso jornalístico - normalização dos sentidos endereçada à moral de rebanho que encharca as massas.

Talvez o valor ético que venha a emergir de uma contracultura do jornalismo revisitada seja nietzschiano por excelência. Um jornalismo alternativo aos apelos ideológicos da democracia como palavra de ordem, para a qual Nietzsche apontava suas armas na figura de sua objeção ao argumento do bem comum:

\begin{abstract}
"É preciso livrar-se do mau gosto de querer estar de acordo com muitos. 'Bem' não é mais bem, quando aparece na boca do vizinho. E como poderia haver um 'bem comum'? O termo se contradiz: o que pode ser comum sempre terá pouco valor. Em última instância, será como é e sempre foi: as grandes coisas ficam para os grandes, os abismos para os produndos, as branduras e os tremores para os sutis e, em resumo, as coisas raras para os raros" ${ }^{\prime 66}$
\end{abstract}

Neste aforismo Nietzsche explora a contradição que o termo 'comum' insere no valor do termo bem. Como explica o tradutor da edição brasileira, Paulo César de Souza, 'comum' em alemão se define pelo termo "gemein", que significa ao mesmo tempo ordinário, vulgar. A refutação do ideal do 'bem comum" por Nietzsche se vale dessa significação: como algo vulgar pode ser um valor se o seu significado é justamente relativo àquilo que não tem valor algum.

\footnotetext{
${ }^{66}$ NIETZSCHE, Friedrich. Para além do Bem e do Mal. São Paulo, Cia das Letras, 1992.
} 
Então o "bem comum" que expressa o valor fundamental da idéia da democracia é contraditório em sua base. Essa valoração ética de Nietzsche é perigosa se o que se tem em mente é algo outro do que a democracia enquanto palavra de ordem - valor totalizante que rebate um mundo submetido à ordem de uma potência imperial imanente. Vista assim a denúncia de Nietzsche assume outra tonalidade, contrastante com a "democracia globalitária" que encarcera suas sombras em Guantanamo. "Bem comum" de um mundo transformado em mônada que se expressa na vulgarização da guerra e do terrorismo - círculo macabro da autofagia de uma serpente que constrói seu infinito ao morder a própria cauda. Tudo isto sustentado pela transparência imobilizadora da qual o jornalismo ocupa a posição de escriba. Cultura de morte que espetaculariza holocaustos.

Ainda seguindo Nietzsche, mas na voz de um de seus mais brilhantes herdeiros: "A liberdade é uma prática... a liberdade dos homens nunca é assegurada pelas leis e instituições que visam a garanti-la. Por isso é que quase todas essas leis e instituições são perfeitamente passíveis de ser invertidas $^{\prime \prime 67}$

Um jornalismo contracultural seria um contra-investimento que depotencializaria a ordem estabelecida pela "moral de rebanho" que se esconde por trás do "bem comum" democrático. Isto demonstra ser pensável a partir da recuperação de um valor ético que foi eclipsado no pensamento político contemporâneo tornando-se secundário em relação ao 'bem comum':

\footnotetext{
"Ser livre, portanto, é ser capaz de questionar a política, de questionar a maneira como o poder é exercido, contestando suas
}

\footnotetext{
${ }^{67}$ FOUCAULT, Michel Apud RAJCHMAN., John. Eros e Verdade - Laca ea Questão da Ética. Rio de Janeiro, Jorge Zahar, 1993.
} 
reivindicações de dominação. Esse questionamento implica nosso ethos, nossas maneiras de ser ou de nos tornarmos o que somos. A liberdade é, pois, uma questão de ética".68

A liberdade, declara Foucault, é a condição ontológica da ética; mas a ética é a forma deliberada assumida pela liberdade. "Se a existência da liberdade na história condiciona a elaboração de uma ética, essa ética é a tentativa de dotar a existência de uma forma prática específica. ${ }^{169}$

É somente em relação à liberdade enquanto valor ético fundamental que se pode pensar uma ruptura com o valor do "bem comum" que sustenta a falsa liberdade democrática que os jornais encenam. Um jornalismo contracultural resgatando a potência do estranhamento que revela o artifício da linguagem é condição necessária para que se fale de uma liberdade outra, fundamental. $\mathrm{O}$ jornalismo como máquina de representar o mundo, mas um mundo povoado por um povo que virá. Uma comunidade que virá. Uma comunidade crítica em termos foucaultianos que se define pela contestação da comunidade tácita que se institui com a democracia enquanto palavra de ordem no jornalismo. Não o anonimato fantasmagórico de uma massa, mas a multiplicidade de sujeitos que se constituem segundo uma ética que entende o valor da liberdade como um devir de suas práticas.

\footnotetext{
${ }^{68}$ RAJCHMAN, John. Op.cit.

${ }^{69}$ Idem.
} 


\section{Conclusão}

Como enquadramento final das idéias aqui desenvolvidas, para além do que elas significam no contexto das práticas da imprensa, colocamos a dimensão do ensino do jornalismo como algo que não deve simplesmente reproduzir modelos derivados das demandas de mercado. Acreditamos que a idéia de uma ruptura a partir da própria concepção de linguagem jornalística é fundamental nesse sentido. É nessa đireção que o presente trabalho busca se colocar. Existem outros possíveis para essas práticas, modelos alternativos que possam responder às crises do contemporâneo e suas projeções na esfera da comunicação.

A filosofia de Deleuze e Guattari é uma referência na construção desse plano de discussões por ser um apelo à diferença e à multiplicidade. Comunicação então passa a significar transferência de força de um corpo a outro - um contra-efeito, um acontecimento. Não a imobilização das massas, mas toda uma agitação molecular. O New Journalism tomado não dentro de uma perspectiva historicista e convencional, pautada por periodizações, escolas, movimentos - assim também como a contraultura, entendida também 
muito mais como uma linha que se abre dentro da história recente do que um conjunto fechado de elementos dispostos numa mera estética de massa. Acima de tudo entender o jornalismo como um agenciamento coletivo de enunciação. Viva o múltiplo! 


\section{Referências Bibliográficas}

ALLIEZ, Eric. (org.). Gilles Deleuze: Uma Vida Filosófica. Rio de Janeiro, Editora 34, 2000.

ALTSCHULL, J. Herbert. From Milton to McLuhan - the ideas behind amerian journalism. New York / London, Longman, 1990.

ANGAMBEN, Giorgio. A Comunidade que Vem. Lisboa, Editorial Presença, 1993.

ARAÚJO, Inês Lacerda. Foucault e a Crítica do Sujeito. Curitiba, Editora UFPR, 2001.

BADIOU, Alain. Deleuze - o clamor do ser. Rio de Janeiro, Jorge Zahar Ed. , 1997.

BADIOU, Alain. Para Uma Nova Teoria do Sujeito. Rio de Janeiro, Relume Dumará, 1994.

BAKHTIN, Mikhail. Marxismo e Filosofia da Linguagem. São Paulo, Hucitec, 1986.

BARRETO, Jorge Lima. Rock\& Droga - antropologia psicodélica e música pop / a cronopatiada droga considerada como o desejo do rock. Lisboa, Ed. \& etc., s.d.

BARROS, Diana Luz Pessoa de, e FIORIN, José Luiz (orgs.). Dialogismo, Polifonia, Intertextualidade. São Paulo, EDUSP, 1994.

BAUDRILLARD, Jean. À Sombra das Maiorias Silenciosas. São Paulo, Brasiliense, 1985.

BAUDRILLARD, Jean. Para uma Crítica da Econo mia Política do Signo. Rio de Janeiro, Elfos Editora, Lisboa, Edições 70, 1995.

BAUDRILLARD, Jean. Simulacros e Simulação. Lisboa, Relógio D’Água, 1991. 
BELAU, Angel Faus. La Ciencia Periodística de Otto Groth. Pamplona, Universidad de Navarra, 1966.

BLANCHOT, Maurice. O Espaço Literário. Rio de Janeiro, Rocco, 1987.

BLANCHOT, Maurice. O Livro do Porvir. Lisboa, Relógio D’Água, 1984.

BOGUE, Ronald. Deleuze and Guattari. Londres/ New York, Routledge, 1989.

BOUNDAS, Constantin V. e OLKOWSKI, Dorothea. Gilles Deleuze and the Theather of Philosophy. New York/ London, Routledge, 1994.

BRANDÃO, Helena H. Nagamine. Subjetividade Argumentação Polifonia - a propaganda da Petrobrás. São Paulo, Fundação Editora da UNESP, Imprensa Oficial do Estado, 1998.

BRANDÃO, Helena Nagamine. Introdução à Análise do Discurso. Campinas, Unicamp, 1991.

BRETON, Philippe. A argumentação na Comunicação. Bauru, EDUSC, 1999.

BROWN, Norman O. Vida Contra Morte. Petrópolis, Vozes, 1974.

CANCLINI, Nestor Garcia. Consumidores e Cidadãos - conflitos multiculturais da globalização. Rio de Janeiro, Editora da UFRJ, 2001.

CANCLINI, Néstor García. Culturas Híbridas. São Paulo, EDUSP, 2000.

CANCLINI, Néstor García. La Globalización Imaginada. Buenos Ayres, Editorial Paidós, 2001.

CARRILHO, Manuel Maria. Elogio da Modernidade. Lisboa, Editorial Presença, 1989.

CHALHUB, Samira. Funções da Linguagem. São Paulo, Ática, 2001.

CHAPARRO, Manuel Carlos. Pragmática do Jornalismo. São Paulo, Summus, 1994. 
CHIPP, H.B. Teorias da Arte Moderna. São Paulo, Martins Fontes, 1996.

COHN, Gabriel (org.). Comunicação e Indústria Cultural. São Paulo, Nacional, 1977.

CONNOR, Steven. Cultura Pós-Moderna. São Paulo, Loyola, 1993.

COSSON, Rildo. Romance-Reportagem: o gênero. Brasília, Editora da UnB, 2001.

CUCHE, Denys. A noção de cultura nas ciências sociais.Bauru, EDUSC, 1999.

DARTON, Robert. Os Best-Sellers Proibidos da França Pré-Revolucionária. São Paulo, Cia de Letras, 1998.

DELEUZE, Gilles e GUATTARI, Félix. Kafka - Por uma literatura menor. Rio de Janeiro, Imago, 1977.

DELEUZE, Gilles e GUATTARI, Félix. Mil Platôs Vol. 1,2,3,4 E 5. Rio de Janeiro, 34, 1995

DELEUZE, Gilles e GUATTARI, Félix. O Anti-Édipo. Rio de Janeiro, Imago, 1976.

DELEUZE, Gilles e GUATTARI, Félix. O que É a Filosofia? São Paulo, 34, 1992.

DELEUZE, Gilles e PARNET, Claire. Diálogos. São Paulo, Escuta, 1998.

DELEUZE, Gilles e PARNET, Claire. Dialogues. Paris, Flamarion, 1996.

DELEUZE, Gilles. Crítica e Clínica. 34, São Paulo, 1997.

DELEUZE, Gilles. Diferença e Repetição. Rio de Janeiro, Graal, 1988.

DELEUZE, Gilles. Espinosa - filosofia prática. São Paulo, Escuta, 2002.

DELEUZE, Gilles. Espinosa e os Signos. Porto, Rés Editora, s/d. 
DELEUZE, Gilles. Nietzsche e a Filosofia. Rio de Janeiro, Editora Rio, 1976

DELEUZE, Gilles. Proust e os Signos. Rio de Janeiro, Forense Universitária, 1987.

DERRIDA, Jacques. Salvo o Nome. Campinas, Papirus, 1993.

DESCHAMPS, Christian. As Idéias Filosóficas Contemporâneas na França. Rio de Janeiro, Jorge Zahar, 1991.

DUARTE RODRIGUES, Adriano. Estratégias da Comunicação. Lisboa, Editorial Presença, s/d.

EAGLETON, Terry. Ideologia. São Paulo, Editora da UNESP / Ed. Boitempo, 1997.

FOUCAULT, Michel. As Palavras e as Coisas. São Paulo, Martins Fontes, 1995.

FREITAG, Barbara. A Teoria Crítica Ontem e Hoje. São Paulo, Brasiliense, 1990.

FREITAS, Jeanne Marie Machado de. Comunicação e Psicanálise. São Paulo, Escuta, 1992.

FREUD, Sigmund. O Mal-Estar na Civilização. Rio de Janeiro, Imago, 1997.

GOLDSTEIN, Richard. Reporting the Counterculture. Boston, Unwin Hyman, 1989.

GOMES, Mayra Rodrigues. Ética e Jornalismo - uma cartografia dos valores. São Paulo, Escrituras Editora, 2002.

GOMES, Mayra Rodrigues. Jornalismo e Ciências da Linguagem. São Paulo, Hacker Editores / EDUSP, 2000.

GOMES, Mayra Rodrigues. Repetição e Diferença nas Reflexões sobre Comunicação. São Paulo, Annablume, 2001. 
GUARESCHI, Pedrinho (coord). Comunicação \& Controle Social. Petrópolis, Vozes, 2001.

GUATTARI, Félix e ROLNIK, Suely. Micropolítica - cartografias do desejo. Petrópolis, Editora Vozes, 1996.

GUATTARI, Felix. Revolução Molecular: pulsações políticas do desejo. São Paulo, Brasiliense, 1981.

HAUSER, Arnold. História Social da Arte e da Literatura. São Paulo, Martins Fontes, 1995.

HOLLANDA, Heloísa Buarque de. Impressões de viagem - CPC, vanguarda e desbunde: 1960-70. Rio de Janeiro, Rocco, 1992.

HOME, Stewart. Assalto à Cultura - Utopia subversão guerrilha na (anti)arte do século XX. São Paulo, Conrad, 1999.

JAMESON, Fredric. Pós-modernismo - A lógica cultural do capitalismo tardio. São Paulo, Ática, 1996.

JEUDY, Henri-Pierre.A Ironia da Comunicação. Porto Alegre, Sulina, 2001.

JOHNSON, Christopher. Derrida. São Paulo, Editora da Unesp, 2001.

JOHNSON, Michael. Te New Journalism - the underground press, the artists of nonfiction, and changes in the established media. Lawrence/ Manhattan / Wichita, University Press of Kansas, 1971.

JULIÃO, José N. A Crítica de Nietzsche à Unidade do Ssujeito. In BRITO, Adriano Naves de e HECK, José N. Interação comunicativa - aproximações filosófico-lingüísticas. Goiânia, Editora UFG, 2000.

KELLNER, Douglas. A Cultura da Mídia. Bauru-SP, EDUSC, 2001.

KRAMER, Jane. Allen Ginsberg in América. New York, Random House, 1969.

KRISTEVA, Julia. A Historiada Linguagem. Lisboa, Edições 70, s.d. 
LAGE, Nilson. Linguagem Jornalística. São Paulo, Ática, 1985.

LEARY, Timothy. Flashbacks - LSD : a experiência que abalou o sistema. São Paulo, Brasiliense, 1989.

LEARY, Timothy. The Psychedelic Reader. Toronto, Carol Publishing Group, 1993.

LEMINSKI, Paulo. Forma é poder. São Paulo,Folhetim de 04/07/1982

LIMA, Edvaldo Pereira. Páginas ampliadas - o livro reportagem como extensão do jornalismo e da literatura. Campinas, Editora da UNICAMP, 1993

LIMA, Luiz Costa (org.). Teoria da Cultura de Massa. São Paulo, Paz e Terra, 2000.

LIMA, Venício A. de. Mídia - Teoria e Política. São Paulo, Editora Fundação Perseu Abramo, 2001.

LINK, Daniel. Como Se Lê e Outras Intervenções Críticas. Chapecó, Argos, 2002.

LOPES, Maria Immacolata Vassalo. Pesquisa em Comunicação. São Paulo, Edições Loyola, 1999.

LUKÁCS, Georg. Ensaios sobre literatura. Rio de Janeiro, Civilização Brasileira, 1965.

MACHADO, Roberto. Nietzsche e a Verdade. Rio de Janeiro, Rocco, 1984.

MACHADO, Roberto. Deleuze e a Filosofia. Rio de Janeiro, Graal, 1990.

MACHADO, Roberto. Foucault, a filosofia e a literatura. Rio de Janeiro, Jorge Zahar Ed. 2001.

MACIEL, Luis Carlos. Nova Consciência - Jornalismo Contracultural - 19701972. Rio de Janeiro, eldorado, 1973.

MACIEL, Luiz Carlos. Geração em Transe - memórias do tempo do tropicalismo. Rio de Janeiro, Nova Fronteira, 1996. 
MAINGUENEAU, Dominique. Termos-Chave da Análise do Discurso. Belo Horizonte, Editora UFMG, 2000.

MARCUSE, Herbert. Eros e Civilização - uma interpretação filosófica do pensamento de Freud. Rio de Janeiro, Jorge Zahar ed. , 1968.

MARCUSE, Herbert. Tecnologia, Guerra e Facismo. São Paulo, Editora da Unesp, 1999.

MARTIN-BARBERO, Jesús. Dos Meios às Mediações. Rio de Janeiro, Editora UFRJ, 2001.

MARTON, Scarlett (org.). Nietzsche Hoje? São Paulo, Brasiliense, 1985.

MATTELART, Armand e Michéle. História das Teorias da Comunicação. São Paulo, d. Loyola, 1999.

MATTELART, Armand. Comunicação Mundo - história das idéias e das estratégias. Petrópolis, Vozes, 2001.

MATTELART, Armand. História da sociedade da Informação. São Paulo, Ed. Loyola, 2002.

MATTESSICH, Stefan. Lines of Flight - Discoursive Time and Countercultural Desire in the Work of Thomas Pynchon. Londres e Durhan, Duke University Press, 2002.

McCLURE, Michael. Scratching the Beat Surface - essays on new vision from blake to Kerouac. New York, Penguin Books, 1982.

McLUHAN, Marshall. Os Meios de comunicação Como Extensões do Homem. São Paulo, Cultrix, 1974.

MEDINA, Cremilda. Notícia- um produto a venda: jornalismo na sociedade

MICHELI, Mário de. As Vanguardas Artísticas. São Paulo, Martins Fontes, 1991. 
MOTTA, Luiz Gonzaga (org.). Imprensa e Poder. Brasília, Editora UnB, 2002.

NEGRI, Antonio e HARDT, Michael. Império. Rio de Janeiro, Record, 2001.

NEGRI, Antonio. Exílio. São Paulo, Iluminuras, 2001.

NEGRI, Antonio. Infinitude da Comunicação / Finitude do Desejo in

NEGRI, Antonio. O Poder Constituinte - ensaio sobre as alternativas da modernidade. Rio de Janeiro, DP\&A, 2002.

NETO, Antônio Fausto. Desmontagens de sentidos - leituras de discursos midiáticos. João Pessoa, Editora Universitária / UFPB, 2001.

NIETZSCHE, Friederich. Além do Bem e do Mal - Prelúdio a uma Filosofia do Futuro. São Paulo, Companhia das Letras, 1992.

OLINTO, Heidrun Krieger e SCHÖLLHAMMER, Karl Erik. Literatura e Mídia. São Paulo, Loyola, 2002.

ORLANDI, Eni Puccinelli. As formas do Silêncio - No Movimento dos sentidos. Campinas, Editora da Unicamp, 1995.

ORLANDI, Eni Puccinelli. Interpretação - autoria, leitura e efeitos do trabalho simbólico. Petrópolis, Vozes, 1996.

ORTEGA, Francisco. Intensidade - para uma história herética da filosofia. Goiânia, Editora da UFG, 1998.

PARENTE, André. Imagem Máquina - a era das tecnologias do virtual. Rio de Janeiro, Editora 34, 1996.

PELBART, Peter Pál. A Nau do Tempo Rei - 7 ensaios sobre o tempo da loucura. Rio de Janeiro, Imago, 1993.

PELBART, Peter Pál. A vertigem por um fio - políticas da subjetividade contemporânea. São Paulo, Iluminuras, 2000.

PELBART, Peter Pál. Da clausura do fora ao fora da clausura - loucura e desrazão. São Paulo, Brasiliense, 1989. 
PEREIRA, Carlos Alberto Messeder. Retrato de Época - Poesia Marginal anos 70. Rio de Janeiro, FUNARTE, 1981.

PETERS, Michael. Pós-Estruturalismo e Filosofia da Diferença - uma introdução. Belo Horizonte, Autêntica, 2000.

PIGNATARI, Décio. Informação, Linguagem, Comunicação. São Paulo, Perspectiva, 1970.

RAGO, Margareth, ORLANDI, Luiz B Lacerda e VEIGA-NETO, Alfredo (orgs.). Imagens de Foucault e Deleuze - ressonâncias nietzshianas. Rio de Janeiro, DP\&A, 2002.

RESENDE, Fernando. Textuações - ficção e fato no jornalismo de Tom Wolfe. São Paulo, Annablume / FAPESP, 2002.

RAJCHMAN., John. Eros e Verdade - Laca ea Questão da Ética. Rio de Janeiro, Jorge Zahar, 1993.

RODRIGUES, Adriano Duarte. Comunicação e Cultura - a experiência cultural na era da informação. Lisboa, Editorial Presença, 1999.

ROSSEAU, Jean-Jacques. Ensaio sobre a origem das línguas. Campinas, Editora da UNICAMP, 1998.

ROSSET, Clement. O real e seu duplo. Porto alegre, LPM, 1984

ROSZAK, Theodore. A Contracultura. Petópolis, Vozes, 1972.

SALVINO, Rômulo Valle. Catatau: as meditações da incerteza. São Paulo, EDUC / FAPESP, 2000.

SANTAELLA, Lúcia. Cultura das Mídias. São Paulo, Razão Social, 1992.

SANTOS, Adriana Barcelar Leite E.. Os Meios de Comunicação como Extensões do Mal-Estar. Rio de Janeiro, Mauad, 2002.

SANTOS, Boaventura Souza. Introdução a Uma Ciência Pós-Moderna. Rio de Janeiro, Graal, 1989. 
SARLO, Beatriz. Cenas da vida pós-moderna - intelectuais, arte e videocultura na Argentina. Rio de Janeiro, editora da UFRJ, 2000.

SCHOPENHAUER, Arthur. O Mundo Como Vontade e Representação. Rio de Janeiro, Contraponto, 2001.

SCHORSKE, Carl E. Viena Fin-de-Siécle - Política e cultura. São Paulo, Companhia das Letras e Editora da Unicamp, 1990.

SERRANI, Silvana M..A Linguagem na Pesquisa Sociocultural - um estudo da repetição na discursividade. Campinas, Editoda da UNICAMP, 1997.

SEVCENKO, Nicolau. Literatura Como Missão. Tensões sociais e criação cultural na Primeira República. São Paulo, Brasiliense, 1983.

SFEZ, Lucien. A Saúde Perfeita - crítica de uma nova utopia. São Paulo, Edições Loyola, 1996.

SFEZ, Lucien. Crítica à Comunicação. São Paulo, Loyola, 1995.

SFEZ, Lucien. Crítica da Comunicação. São Paulo, Ed. Loyola, 2000.

SOLOMON, Carl. De Repente Acidentes. Porto Alegre, LP\&M, 1985.

SILBERMAN, Steve e SHENK, David. Skeleton Key - A Dictionary for Deadheads. New York, Main Street Bookes - Doubleday, 1994.

STAM, Robert. Bakhtin- da teoria literária à cultura de massa. São Paulo, Ática, 1992.

STEPHENS. Julie. Anti-Disciplinary Protest - Sixties Radicalism and Postmodernism. Melbourne/Austrália, Cambridge University, 1998.

TEIXEIRA COELHO NETO, J. Guerras Culturais. São Paulo, Iluminuras, 2000 .

THEMUDO, Thiago Seixas. Por uma sociologia do intensivo in: LINS, Daniel (org et alli.). Nietzsche e Deleuze - intensidade e paixão. Rio de Janeiro, Relume Dumará, 2000. 
WALKER, John A. A Arte desde o Pop. Barcelona, Editorial Labor, 1977.

WARNIER, Jean-Pierre. A mundialização da cultura. Bauru, EDUSC, 2000.

WISNIK, José Miguel. Ilusões Perdidas in NOVAES, Adauto (org) Ética. Cia das Letras, São Paulo, 1992.

WOLF, Mauro. Teorias da Comunicação. Lisboa, Editorial Presença, 1999.

WOLFE, Tom. Décadas Púrpuras. Porto alegre, PL\&M, 1989.

WOLFE, Tom. The New Journalism. Nova York. Harper \& Row, 1973.

ZIZEK, Slavoj. Organs Without Bodies: Deleuze and consequences. New York/ London, Routledge, 2003. 